\title{
Chimeric Antigen Receptor-T Cells: A Pharmaceutical Scope
}

\author{
Alejandrina Hernández-López ${ }^{1}$, Mario A. Téllez-González ${ }^{1,2}$, Paul Mondragón-Terán ${ }^{2}$ and \\ Angélica Meneses-Acosta ${ }^{1 *}$ \\ ${ }^{1}$ Laboratorio 7 Biotecnología Farmacéutica, Facultad de Farmacia, Universidad Autónoma Del Estado de Morelos, UAEM, \\ Cuernavaca, Mexico, ${ }^{2}$ Coordinación de Investigación, Centro Médico Nacional "20 de Noviembre" ISSSTE, Mexico city, Mexico
}

Cancer is among the leading causes of death worldwide. Therefore, improving cancer therapeutic strategies using novel alternatives is a top priority on the contemporary scientific agenda. An example of such strategies is immunotherapy, which is based on teaching the immune system to recognize, attack, and kill malignant cancer cells. Several types of immunotherapies are currently used to treat cancer, including adoptive cell therapy (ACT). Chimeric Antigen Receptors therapy (CAR therapy) is a kind of ATC where autologous $T$ cells are genetically engineered to express CARs (CAR-T cells) to specifically kill the tumor cells. CAR-T cell therapy is an opportunity to treat patients that have not responded to other first-line cancer treatments. Nowadays, this type of therapy still has many challenges to overcome to be considered as a first-line clinical treatment. This emerging technology is still classified as an advanced therapy from the pharmaceutical point of view, hence, for it to be applied it must firstly meet certain requirements demanded by the authority. For this reason, the aim of this review is to present a global vision of different immunotherapies and focus on CAR-T cell technology analyzing its elements, its history, and its challenges. Furthermore, analyzing the opportunity areas for CAR-T technology to become an affordable treatment modality taking the basic, clinical, and practical aspects into consideration.

Keywords: CAR-T cells therapy, cell and gene therapy, advanced cell therapy, cell manufacturing process, immunotherapy

\section{INTRODUCTION}

Cancer is a major health issue worldwide, causing a serious health problem that affects costs on public health, social development and, most importantly, reducing people's life expectancy (Bray et al., 2018; Hassanpour and Dehghani 2017). In a broader context, cancer refers to more than 277 different types of cancer diseases (Hassanpour and Dehghani 2017), which represent major challenges to find out specific diagnosis and treatment. Worldwide, the main incidence of cancer types in adults occurs in the prostate, lung, bronchus, colon, rectum, urinary bladder, breast, and thyroid (Siegel et al., 2019), meanwhile, blood cancer is the main cancer type of concern in children's health (Kolonel and Wilkens). For years, the most effective cancer treatments have included surgery, chemotherapy, radiation therapy and bone marrow transplant (Arruebo et al., 2011), these therapies are considered as the main treatment. Unfortunately, even considering the current technological improvements on such therapies, recurrence and metastasis are still the main causes of death (Bray et al., 2018). In recent years, these common treatments have been challenged with the advent of immunotherapy.

Immunotherapies are designed to harness and manipulate part of the immune system to confer the ability to detect and specifically attack cancer cells (Waldmann 2003). Immunotherapies 
TABLE 1 | Six major kinds of cancer immunotherapy.

\begin{tabular}{|c|c|c|c|}
\hline $\begin{array}{l}\text { Cancer } \\
\text { immunotherapy }\end{array}$ & Description & Indications & References \\
\hline Checkpoint inhibitors & $\begin{array}{l}\text { This treatment takes the brakes off the immune system, } \\
\text { helping it to identify and attack cancer cells. Checkpoint } \\
\text { inhibitor therapies have been discovered and studied for } \\
\text { cancer treatment based on CTLA-4 and PD-1 }\end{array}$ & $\begin{array}{l}\text { Pleural mesothelioma, classical Hodgkin's lymphoma, } \\
\text { Merkel cell and cutaneous squamous cell carcinoma, head } \\
\text { and neck cancer, triple negative breast cancer, lung, } \\
\text { colorectal, kidney, bladder, cervical, endometrial, liver and } \\
\text { stomach cancers, as well non-blood cancers that test } \\
\text { positive for the biomarkers MSI-high/dMMR, tumor } \\
\text { mutation burden high esophageal squamous cell, renal cell, } \\
\text { urothelial carcinoma, and primary mediastinal large B cell } \\
\text { lymphoma }\end{array}$ & $\begin{array}{l}\text { Darvin et al. (2018) } \\
\text { Sang et al. (2019) } \\
\text { Twomey \& Zhang } \\
\text { (2021) }\end{array}$ \\
\hline Cytokines & $\begin{array}{l}\text { This treatment promotes the activation of several important } \\
\text { specialized cellular functions to boost the body's immune } \\
\text { system }\end{array}$ & $\begin{array}{l}\text { Advanced melanomas, kidney, liver, lung, head and neck, } \\
\text { breast, ovarian, cervical, prostate, pancreatic, colorectal, } \\
\text { bladder, gastric, brain cancers, Sarcomas, hematological } \\
\text { malignancies }\end{array}$ & $\begin{array}{l}\text { Berraondo et al. } \\
\text { (2019) } \\
\text { Parmiani et al. (2000) } \\
\text { Qiu et al. (2021) }\end{array}$ \\
\hline $\begin{array}{l}\text { Monoclonal antibodies } \\
\text { (mAbs) }\end{array}$ & $\begin{array}{l}\text { mAbs have an unique antigen specificity that allows them to } \\
\text { bind to specific epitopes on cancer cells and kill them by } \\
\text { different mechanisms. For example, they can induce } \\
\text { apoptotic cell death or the attack by NK cells due to the } \\
\text { ADCC action }\end{array}$ & $\begin{array}{l}\text { Non-Hodgkin's and Hodgkin's lymphoma, triple negative } \\
\text { breast cancer, melanoma, chronic lymphocytic leukemia, } \\
\text { non-small cell lung cancer, chronic myeloid leukemia, acute } \\
\text { lymphoblastic leukemia, multiple myeloma, gastric, } \\
\text { bladder, breast, colorectal cancers, hairy cell leukemia }\end{array}$ & $\begin{array}{l}\text { Ventola (2017) } \\
\text { Golay and Taylor } \\
\text { (2020) } \\
\text { Zahavi \& Weiner } \\
\text { (2020) } \\
\text { Monajati et al. (2021) }\end{array}$ \\
\hline Cancer vaccines & $\begin{array}{l}\text { Vaccines teach and stimulate the body's immune system to } \\
\text { find, attack and eradicate cancer cells }\end{array}$ & Cervical, vaginal, vulvar, anal, liver, and prostate cancers & $\begin{array}{l}\text { Karlitepe et al. (2015) } \\
\text { Miao et al. (2021) }\end{array}$ \\
\hline Oncolytic viruses & $\begin{array}{l}\text { This treatment uses modified viruses, such as } \\
\text { coxsackievirus, adenovirus, reovirus, herpes simplex virus, } \\
\text { and measles virus to infect, replicate and kill neoplastic cells }\end{array}$ & Melanoma and lymph nodes & $\begin{array}{l}\text { Anelone et al. (2020) } \\
\text { Mondal et al. (2020) } \\
\text { Nejad et al. (2021) }\end{array}$ \\
\hline $\begin{array}{l}\text { Adoptive Cell } \\
\text { Therapy (ACT) }\end{array}$ & $\begin{array}{l}\text { This treatment modifies the body's own immune cell to } \\
\text { become a cancer treatment drug. ACT can be deployed in } \\
\text { different ways such as TIL, TCR, NK or CAR-T therapy }\end{array}$ & $\begin{array}{l}\text { CAR-T therapy for B-cell precursor acute lymphoblastic } \\
\text { leukemia, diffuse large B-cell lymphoma, relapsed or } \\
\text { refractory follicular lymphoma, mantle cell lymphoma, } \\
\text { relapsed or refractory large B-cell lymphomas and multiple } \\
\text { myeloma }\end{array}$ & $\begin{array}{l}\text { Maude et al. (2018) } \\
\text { Guedan et al. (2019) } \\
\text { Rohaan, et al. (2019) } \\
\text { Schuster et al. (2019) } \\
\text { Iragavarapu and } \\
\text { Hildebrandt (2021) } \\
\text { Munshi et al. (2021) }\end{array}$ \\
\hline
\end{tabular}

(CTLA-4, Cytotoxic T-lymphocyte-associated antigen 4; PD-1 Programmed Death 1: MSI-high, microsatellite instability-high; dMMR, mismatch repair deficient; ADCC, Antibodydependent cellular cytotoxicity; TIL, Tumor-Infiltrating Lymphocytes; TCR, gene-modified T cells expressing novel T Cell Receptors, NK, Natural Killer cells; CAR, Chimeric Antigen Receptors).

introduce a different perspective into cancer treatment, not only in patients with refractory tumors, but also to ensure long-lasting clinical remission in patients that were historically considered incurable (Dougan and Dranoff 2012; Guedan et al., 2019). Hence, in this paper we intend to expose the general panorama regarding immunotherapies, focusing the effort to the novel CAR-T cell therapy, its components, advantages, and limitations, summarizing the current challenges which need to be overcome and discussing the actual strategies to implement this therapy with a wider scope in benefit of a larger number of patients.

\section{IMMUNOTHERAPY, A NEW APPROACH FOR CANCER TREATMENT}

Chemotherapy, radiation, and surgery are the most conventional cancer treatments, nevertheless, they have shown low efficacy and severe adverse effects. Therefore, during the last decade, researchers have addressed the need to improve the inconveniences with conventional cancer therapy, developing new strategies to achieve complete remission of the disease using molecular strategies. Under these circumstances, immunotherapy arises as a promise for revolutionary cancer treatment, because, compared with conventional therapeutics, it leads to lower side effects and can specifically target cancer cells by regulating the immune system's machinery (Papaioannou et al., 2016; Sang et al., 2019). Therefore, immunotherapy has become an important therapeutic alternative for patients whose immune systems are already compromised due to their advanced disease and/or failure of previous conventional therapies (Ventola, 2017; Charmsaz et al., 2019). Table 1 covers the six major kinds of available cancer immunotherapies. The most recent immunotherapy that has shown promising results is the Chimeric Antigen Receptor (CAR)-T cell therapy, which is a type of Adoptive Cell Therapy (ACT). This therapeutic strategy entails genetically engineering a patient's T cells to express CARs that recognize, bind, attack and kill tumoral cells (Mirzaei et al., 2017).

\section{A Brief History of Chimeric Antigen Receptor-T Cells Development}

To start with the historical review of the discovery of these new technologies, it is necessary to date the first bone marrow transplant for leukemia patients that was reported in 1957 by Thomas and colleagues (Thomas et al., 1957). A few years later, 
Miller J. and colleagues reported the immunological function of the timus, discovering the origin of T cells (Miller, 1961).

However, it was not until 1986, when Steven Rosenberg and colleagues reported a study about Tumor-Infiltrating Lymphocytes (TILs), this therapy consists of cellular isolation of $\mathrm{T}$ lymphocytes from a tumor, that is subjected to an in vitro culture and expansion to infiltrate them back into the tumor to be treated, hence leading to elimination or clinical resection of the tumor (Rosenberg et al., 1986; Lança and Silva-Santos, 2012; Garber 2019). This report allowed us to fix the gaze on the idea of "Patients' own immune cells can fight their own cancer".

Likewise, results of the successful $\mathrm{T}$ cell transfections of Sadelain and colleagues in 1992 and their methods publications for retrovirus-mediated gene transfer into primary T-lymphocytes in 1997, allowed genetic modifications providing the means of controlling immunity in an experimental or therapeutic setting (Sadelain and Mulligan, 1992; Sadelain, 1997). Almost at the same time, Zelig Eshhar and colleagues designed a specific activation of cytotoxic lymphocytes through chimeric single chains, using an antibody-binding domain and the $\gamma$ or $\zeta$ subunits of the immunoglobulin on the T-cell receptors, developing the First Generation of CAR-T cells (Eshhar et al., 1993). Five years later, Dr. Sadelain's group demonstrated that the integration of a co-stimulatory signal like CD28 to a CAR-T enhanced survival, proliferation and remained active, leading to the development of the Second Generation of CARs (Krause et al., 1998). The pioneering work of Dr. Carl June and his group (University of Pennsylvania) lead to the development of CAR therapy (Kalos et al., 2011), with the approach of using modified $\mathrm{T}$ lymphocytes that carried a CAR to target $\mathrm{CD} 19^{+}$leukemic B cells (Varadé et al., 2021). Such an approach was because the expression of the transmembrane glycoprotein CD19 is maintained during differentiation of B lineage at normal (14\% in peripheral blood lymphocyte phenotype) (Berron-Ruiz et al., 2016) and neoplastic B cells malignancies ( $80 \%$ of ALL, $88 \%$ of B cell lymphomas and $100 \%$ of B cell leukemias) (Wang et al., 2012), as well as follicular dendritic cells. Nowadays, CD19 expression is widely used for the diagnosis of leukemias and lymphomas and is used as the main target for the redirection of $\mathrm{T}$ lymphocytes against these neoplastic associated molecules (Scheuermann and Racila 1995; Tedder, 2009; Wang et al., 2012). In 2009, Isabelle Rivière group published the manufacturing validation of biologically functional $T$ cells targeted to CD19 antigen basing their work on promising data in the eradication of systemic B cell malignancies. This publication launched phase I clinical trials in chronic lymphocytic leukemia (CLL) and acute lymphoblastic leukemia (ALL) (Hollyman et al., 2009). CD19 expression is widely used for the diagnosis of leukemias and lymphomas and used as the main target for the redirection of $\mathrm{T}$ lymphocytes against these neoplastic associated molecules (Scheuermann and Racila 1995; Tedder, 2009; Wang et al., 2012) even though there may be more specific receptors for tumor cells.

The publication of the phase I clinical trial results, proving that CAR-T therapy-induced molecular remissions in adults with chemotherapy-refractory ALL (Brentjens et al., 2013; Grupp et al., 2013), was followed by a scale-up of bioprocess production. Finally, FDA approved the CD 19 CAR-T cell therapy (Tisagenlecleucel) for ALL in children and young adults (U.S. Food and Drug Administrations, 2021a). In addition, in 2021 the FDA approved the use of CAR-T cells using the B-cell maturation antigen ("BCMA" target (Idecabtagene vicleucel) in multiple myeloma (U.S. Food and Drug Administrations, 2021b).

During the first commercial lustrum of CAR immunotherapy, CAR-T therapy explored different applications in other malignancies associated with the initial biomolecules as large B-cell lymphoma (DLBCL), DLBCL arising from follicular lymphoma and high-grade B-cell lymphoma (YESCARTA U.S. Food and Drug Administrations, 2021c). So far, most studies are carried out on the discovery of other targets such as CD20, CD22, CD30 and new targets in solid tumors to increase the scope of CAR-T therapy (Elahi et al., 2018; Castella et al., 2020).

Profiting the clinical successes, the use of CAR-T cells has also been explored in a variety of cancers (Petersen and Krenciute 2019) such as diffuse large B-cell lymphoma treatments in adults and multiple myeloma (Mullard 2017; Iragavarapu and Hildebrandt 2021; Munshi, et al., 2021) in which the therapeutic products were recently approved by the Food and Drug Administration (FDA, United States). Meanwhile, the European Medicines Agency (EMA) has granted conditional approval, or their authorization is currently under review. CAR-T cells re-targeted against the ubiquitous B-cell antigen, CD19 are a remarkable innovation in the treatment of relapsed and/or refractory $(\mathrm{R} / \mathrm{R})$ B-cell acute lymphoblastic leukemia (B-ALL) (Nie et al., 2020). The success of CAR T-cells therapy in cancer is exemplified by numerous clinical trials that have shown that 70-90\% complete remission (CR) can be achieved in pediatric and adult patients treated with CD19-directed CAR T-cells (Xu et al., 2019). Based on these growing CAR-T cell immunotherapy achievements, over 500 clinical trials worldwide analyzing CAR-T cells for the treatment of cancer are currently being under evaluation, and the majority are being performed in East Asia (269 trials), followed by the US (225 trials), and Europe (62 ongoing studies) (as registered at clinicaltrials.gov Q3 2020) (Albinger et al., 2021). So far, five CAR-T cell therapy agents were approved by FDA for cancer treatment: Tisagenlecleucel $\left(\right.$ Kyrmriah $\left.^{\circledR}\right)$ for treatment of acute lymphoblastic leukemia (ALL) (Mullard 2017), Axicabtagene ciloleucel (Yescarta ${ }^{\mathrm{TM}}$ ) for diffuse large B-cell lymphoma (DLBCL) and also FDA-approval for follicular lymphoma in april 2021 (Bouchkouj et al., 2019), Brexucabtagene autoleucel (Tecartus ${ }^{\mathrm{TM}}$ ) for treatment of mantle cell lymphoma (MCL) (Al-Juhaishi and Ahmed, 2021), Idecabtagene vicleucel $\left(\mathrm{ABECMA}^{\circledR}\right)$ for treatment of multiple myeloma (Munshi et al., 2021) and Lisocabtagene maraleucel $\left(\right.$ Breyanzi ${ }^{\circledR}$ ) for diffuse large B-cell lymphoma treatment (Iragavarapu and Hildebrandt 2021) (Table 2).

\section{Chimeric Antigen Receptor T Cell Immunotherapy}

CAR immunotherapy is a successful innovation in cancer therapies achieving impressive results in the treatment of resistant hematological malignancies highlighting its strong 
TABLE 2 | Currently approved CAR-T cells products by FDA and EMA. These are the available products up to July 2021.

\begin{tabular}{|c|c|c|c|c|c|}
\hline Brand name & Kymriah & Yescarta & Tecartus & ABECMA & Breyanzi \\
\hline Generic name & Tisagenlecleucel & Axicabtagene ciloleucel & $\begin{array}{l}\text { Brexucabtagene } \\
\text { autoleucel }\end{array}$ & Idecabtagene vicleucel & Lisocabtagene maraleucel \\
\hline Indication/s & $\begin{array}{l}\text { Treatment of pediatric and } \\
\text { young adult patients (age 3-25 } \\
\text { years) with B-cell ALL that is } \\
\text { refractory or in second or later } \\
\text { relapse } \\
\text { Adult patients with ( } r / r \text { ) LBCL } \\
\text { after two or more lines of } \\
\text { systemic therapy including } \\
\text { DLBCL, HGBL and DLBCL } \\
\text { arising from FL }\end{array}$ & $\begin{array}{l}\text { Treatment of adult patients } \\
\text { with }(r / r) \text { LBCL after two or } \\
\text { more lines of systemic } \\
\text { therapy, PMBCL, HGBL, } \\
\text { and DLBCL arising from FL }\end{array}$ & $\begin{array}{l}\text { Treatment of adult } \\
\text { patients with ( } \mathrm{r} / \mathrm{r} \mathrm{MCL})\end{array}$ & $\begin{array}{l}\text { Treatment of adult patients } \\
\text { with R/R MM after four or } \\
\text { more prior lines of therapy }\end{array}$ & $\begin{array}{l}\text { Treatment of adult patients } \\
\text { with } r / r \text { DLBCL after two or } \\
\text { more lines of systemic } \\
\text { therapy, HGBL, PMBCL, } \\
\text { and FL grade } 3 B\end{array}$ \\
\hline Target. & CD19 & CD19 & CD19 & BCMA & CD19 \\
\hline Company & $\begin{array}{l}\text { Novartis Pharmaceuticals } \\
\text { Corporation }\end{array}$ & Kite Pharma/Gilead & Kite Pharma/Gilead & $\begin{array}{l}\text { Bristol Myers Squibb/ } \\
\text { Bluebird bio }\end{array}$ & Juno/Bristol Myers Squibb \\
\hline Price (USD) & $\$ 475,000$ & $\$ 373,000$ & $\$ 373,000$ & $\$ 419,500$ & $\$ 410,300$ \\
\hline $\begin{array}{l}\text { Approval date } \\
\text { by FDA. }\end{array}$ & $\begin{array}{l}\text { LLA; August 2017. DLBCL, } \\
\text { HGBL and DLBCL arising from } \\
\text { FL; april } 2018\end{array}$ & $\begin{array}{l}\text { LBCL; October } 2017 \\
\text { FL; april } 2021\end{array}$ & July 2020 & March 2021 & February 2021 \\
\hline $\begin{array}{l}\text { Authorization } \\
\text { date by EMA. }\end{array}$ & August 2018 & August 2018 & $\begin{array}{l}\text { Conditional approval, } \\
\text { October } 2020\end{array}$ & $\begin{array}{l}\text { Recommended granting a } \\
\text { conditional marketing } \\
\text { authorization, June } 2021\end{array}$ & $\begin{array}{l}\text { PRIME status. Marketing } \\
\text { Authorization Application } \\
\text { (MAA) is currently under } \\
\text { review }\end{array}$ \\
\hline $\begin{array}{l}\text { Study of efficacy } \\
\text { and safety }\end{array}$ & $\begin{array}{l}\text { JULIET for DLBCL ELIANA for } \\
\text { B-ALL }\end{array}$ & ZUMA-1 & ZUMA-2 & KarMMa & TRANSCEND \\
\hline Clinical trial & $\begin{array}{l}\text { JULIET: NCT02445248 } \\
\text { ELIANA: NCT02435849 }\end{array}$ & NCT02348216 & NCT02601313 & NCT03361748 & NCT02631044 \\
\hline $\begin{array}{l}\text { Enrolled } \\
\text { participants in } \\
\text { the clinical trial }\end{array}$ & 115 & 307 & 105 & 149 & 314 \\
\hline $\begin{array}{l}\text { Number of } \\
\text { treated patients }\end{array}$ & 79 & Data not available & Data not available & Data not available & Data not available \\
\hline Success rate & $\begin{array}{l}83 \% \text { of patients achieved CR } \\
\text { for LLA }\end{array}$ & $\begin{array}{l}54 \% \text { of patients } \\
\text { achieved CR. }\end{array}$ & $\begin{array}{l}67 \% \text { of patients } \\
\text { achieved CR. }\end{array}$ & $39 \%$ of patients achieved CR. & $\begin{array}{l}53 \% \text { of patients } \\
\text { achieved CR. }\end{array}$ \\
\hline & $\begin{array}{l}65 \% \text { of patients achieved CR } \\
\text { for } r / r \text { FL }\end{array}$ & $\begin{array}{l}82 \% \text { achieved an overall } \\
\text { response }\end{array}$ & $\begin{array}{l}92 \% \text { achieved an } \\
\text { overall response }\end{array}$ & $\begin{array}{l}81 \% \text { achieved an overall } \\
\text { response }\end{array}$ & $\begin{array}{l}73 \% \text { achieved an overall } \\
\text { response }\end{array}$ \\
\hline \multirow[t]{2}{*}{ Adverse effects } & $\begin{array}{l}\text { CRS occurred in } 79 \% \text { of } \\
\text { pediatric patients, } 74 \% \text { in } \\
\text { young adult patients with } r / r \\
\text { ALL and } 23 \% \text { in patients with } \\
r / r \text { DLBCL }\end{array}$ & $\begin{array}{l}\text { CRS occurred in } 94 \% \text { of } \\
\text { patients with } L B C L \text { including } \\
\text { four patients who had } \\
\text { ongoing CRS events at the } \\
\text { time of death }\end{array}$ & $\begin{array}{l}\text { CRS occurred in } 91 \% \\
\text { of patients, including } \\
\text { one fatality }\end{array}$ & $\begin{array}{l}\text { CRS occurred in } 85 \% \text { of } \\
\text { patients including one fatality }\end{array}$ & $\begin{array}{l}\text { CRS occurred in } 46 \% \text { of } \\
\text { patients including one fatality } \\
\text { and two had ongoing CRS at } \\
\text { the time of death }\end{array}$ \\
\hline & $\begin{array}{l}\text { NTX occurred in } 72 \% \text { of } \\
\text { patients with } r / r \text { ALL and } 58 \% \\
\text { of patients with } r / r \text { DLBCL }\end{array}$ & $\begin{array}{l}\text { NTX occurred in } 87 \% \text { of } \\
\text { patients with LBCL. }\end{array}$ & $\begin{array}{l}\text { NTX occurred in } 81 \% \\
\text { of patients }\end{array}$ & $\begin{array}{l}\text { NTX of any grade occurred in } \\
28 \% \text { of patients, including } \\
\text { one patient who had ongoing } \\
\text { Grade } 2 \text { neurotoxicity at the } \\
\text { time of death }\end{array}$ & $\begin{array}{l}\text { NTX occurred in } 35 \% \text { of } \\
\text { patients. Three patients had } \\
\text { fatal NTX and seven had } \\
\text { ongoing NTX at the time of } \\
\text { death }\end{array}$ \\
\hline
\end{tabular}

Large B-cell lymphoma (LBCL), diffuse large B-cell lymphoma (DLBCL), High-grade B-cell lymphoma (HGBL), Follicular lymphoma (FL), Primary mediastinal large B-cell lymphoma (PMBCL), relapsed/refractory mantle cell lymphoma (r/r MCL), relapsed or refractory multiple myeloma (r/r MM), refractory follicular lymphoma (r/r FL), Cytokine release syndrome (CRS), Neurotoxicity (NTX), complete remission (CR), non-Hodgkin lymphoma (NHL), PRlority Medicines (PRIME).

potential (Neelapu et al., 2017). CAR-T cell immunotherapy was developed out of the need for $\mathrm{T}$ cells to be able to directly recognize tumor cells without the required antigen processing or presentation by professional antigen-presenting cells (Varadé et al., 2021). This immunotherapy is based on T-cell engineering and the use of synthetic (recombinant) receptors, termed CARs, instead of the physiological (native) receptor for the antigen, the TCR (Sadelain et al., 2009). These CARs are based on a specific antibody directed to a target surface molecule and were developed with the intent of combining the tumor recognition capabilities of antibodies with the powerful antitumor effector abilities of $\mathrm{T}$ cells.
CAR expression is most often achieved using retroviral- or lentiviral-mediated gene transfer. The $\mathrm{T}$ cell's rapidly dividing nature facilitates viral integration, and its ability to establish memory serves to reinforce long-lasting transgene expression (Grosser et al., 2019). Besides, CARs constructions include all the elements necessary for intracellular signaling and activation of helper and cytotoxic T lymphocytes (Singh and McGuirk 2020).

\section{Target Selection}

CAR recognition of malignant cells depends on the designed chimeric recognition molecule, not on the traditional 
TABLE 3 | Novel targets for hematologic malignancies and solid tumors.

\begin{tabular}{|c|c|c|c|c|}
\hline Target & Diseases & Identifier & Status & References \\
\hline & Hematologic malignancies & & & \\
\hline \multirow[t]{2}{*}{ BCMA } & Multiple myeloma & NCT03502577 & Recruiting, phase I & Pont et al. (2019) \\
\hline & & NCT04309981 & Recruiting, phase I/II. & \\
\hline \multirow[t]{2}{*}{ CD38 } & Multiple myeloma & NCT03464916 & Recruiting, phase I & Freitag, et al. (2020) \\
\hline & & NCT03767751 & Recruiting, phase I/II. & Nair, et al. (2019) \\
\hline SLAMF7 & Multiple myeloma & NCT04499339 & Recruiting, phase I/II. & $\begin{array}{l}\text { Rodríguez-Otero et al. } \\
\text { (2020) }\end{array}$ \\
\hline \multirow[t]{2}{*}{ CD33 } & Acute myeloid leukemia & NCT03971799 & Recruiting, phase I/II. & Freitag et al. (2020) \\
\hline & & NCT03126864 & Recruiting, phase I/II. & \\
\hline \multirow[t]{2}{*}{ CD123 } & Acute myeloid leukemia & NCT04014881 & Recruiting, phase I & Hansrivijit et al. (2019) \\
\hline & & NCT03766126 & Not recruiting, phase I & Hoffmann et al. (2018) \\
\hline \multirow[t]{2}{*}{ CD56 } & Multiple myeloma & NCT03473496 & Recruiting & Freitag et al. (2020) \\
\hline & & NCT03271632 & Recruiting, phase I/II. & \\
\hline \multirow[t]{2}{*}{ CD37 } & B- and T-cell lymphoma & NCT04136275 & Recruiting, phase I/ & Scarfò et al. (2018) \\
\hline & Solid tumors & & & \\
\hline \multirow[t]{2}{*}{ EGFRVIII } & Glioblastoma & NCT03283631 & Recruiting temporally & Martinez and Moon \\
\hline & & & suspended, phase I & $(2019)$ \\
\hline GPC3 & Hepatocellular carcinoma & NCT03146234 & Not recruiting & $\begin{array}{l}\text { Da Fonseca and Carrilho } \\
\text { (2019) }\end{array}$ \\
\hline \multirow[t]{2}{*}{ GD2 } & Glioma, cervical cancer, sarcoma, neuroblastoma & NCT03373097 & Recruiting, phase I/II. & Townsend, et al. (2018) \\
\hline & & NCT02761915 & $\begin{array}{l}\text { Recruitment completed, } \\
\text { phase I }\end{array}$ & \\
\hline \multirow[t]{3}{*}{ HER2 } & CNS tumour & NCT03500991 & Recruiting, phase I & Mirzaei, et al. (2017) \\
\hline & & NCT02442297 & & \\
\hline & & NCT00902044 & & \\
\hline \multirow[t]{2}{*}{ Mesothelin } & pancreatic cancer, ovarian Cancer, lung Cancer, peritoneal carcinoma, & NCT03054298 & Recruiting, phase I & Haas et al. (2019) \\
\hline & fallopian tube cancer, mesotheliomas Pleural & NCT03323944 & & \\
\hline Claudin & Gastric cancer, pancreatic cancer & NCT03874897 & Recruiting, phase I & Springuel et al. (2019) \\
\hline 18.2 & & NCT03159819 & & \\
\hline Muc1 & Breast Cancer & NCT04020575 & Recruiting, phase I & Bamdad et al. (2019) \\
\hline ROR1 & Breast cancer, lung cancer & NCT02706392 & Recruiting, phase I & Springuel et al. (2019) \\
\hline
\end{tabular}

BCMA, B-cell maturation antigen; CD, cluster of differentiation; SLAMF7, SLAM Family Member 7; EGFRVIII, variant III of the epidermal growth factor receptor; GPC3, glypican 3; GD2, disialoganglioside; HER2, human epidermal growth factor receptor 2; Muc1, mucin 1; ROR1, Receptor Tyrosine kinase Like Orphan Receptor 1.

T-lymphocyte receptor (TCR) or human leukocyte antigen (HLA). This interaction between CAR and the target leads to the formation of immune synapses, where contact-dependent cytotoxicity occurs. Hence, choosing a target with high specificity and high coverage is the main objective for these therapies. Unfortunately, nowadays there is no guide with uniform criteria that shows how a target should be properly selected, however, it is important to consider that not only membrane proteins are useful, also carbohydrates and glycolipid molecules can be selected if they adapt to the clinical needs of the desired disease (Wang et al., 2017; Wei et al., 2019).

It is recommended to identify and use a target that achieves adequate coverage of tumor cells with enough specificity to prevent CAR activation in other sites that could lead to serious damage in organs. Hence, this way, it is possible to avoid the main toxic side effects in CAR-T treatment, such as cytokine release syndrome (CRS), and the "off-tumor" effect caused by damage to non-tumor cells (Liu et al., 2019).

Recently, different types of CAR have been designed to take into consideration the coverage of two selected targets and the specificity for different types of solid tumors that share proteins involved in cell malignancy. Developed strategies are known as, Pooled CAR: two CAR in the same vector; Dual CAR: crosscompliance where the first target has the signaling domain while the other one has the costimulatory domain, CAR in tandem: where two variable fraction chains are attached to the same antigen-binding domain and some others where activation or function would be inhibited by an inhibitory CAR. The previous designs will further expand CAR-T cell therapy in clinical trials (Fedorov et al., 2013; Hartmann et al., 2017). Since novel targets are currently studied, in a further section, the specific antigens are presented as a strategy to improve the CAR-T cells application (Table 3).

The major advantage of cell-based therapies is the variety of surface proteins that can be used as targets, which allow the specific antigen recognition in an independent manner of the major histocompatibility complex (MHC), in contrast to TCRmediated antigen recognition ( $\mathrm{Li}$ et al., 2018; Dwivedi et al., 2019), that deliver remarkable results in the clinic, specifically for the treatment of B cell malignancies (Grupp et al., 2013; Porter et al., 2015).

\section{Chimeric Antigen Receptor Designs}

In detail, the CAR is a synthetic receptor that ligates to a surface antigen and transduces the protein target of recognition into a signaling cascade (Brown and Mackall, 2019; Qin et al., 2021). The molecular architecture of CAR consists of four main components: 1) antigen-binding (recognition) domain, which 

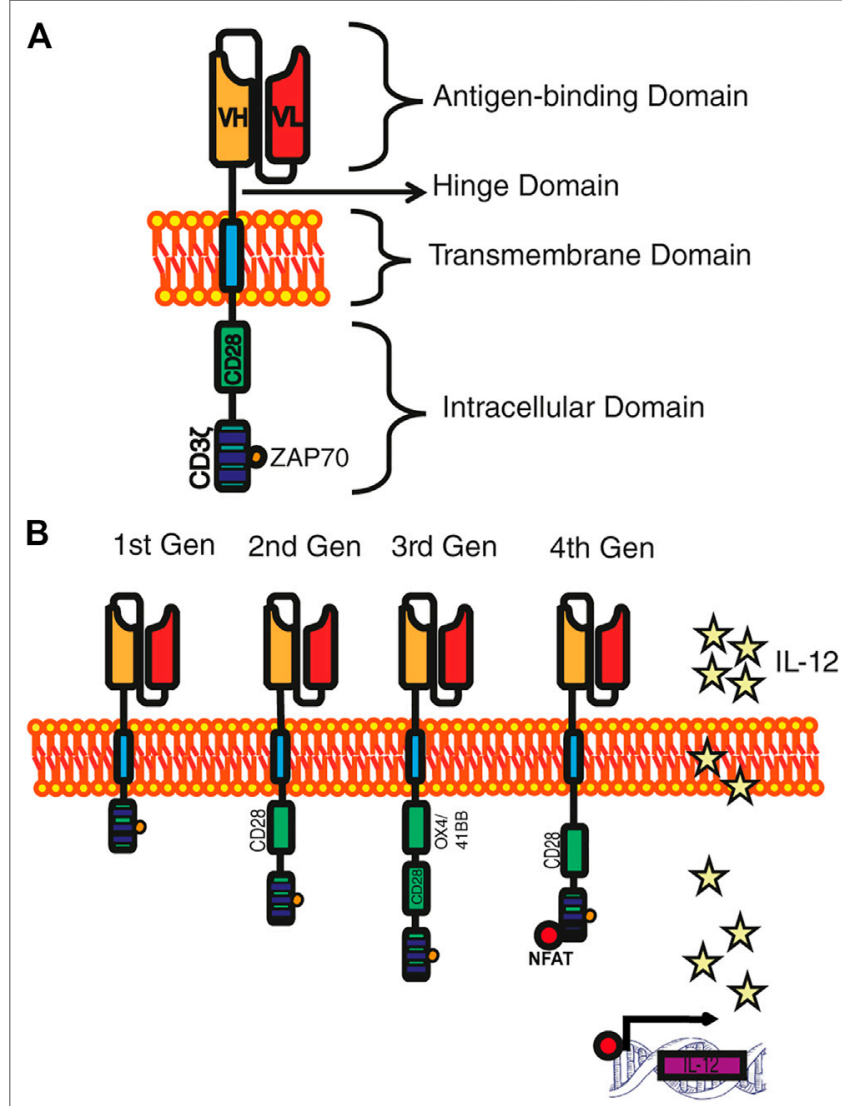

FIGURE 1 | Development of CAR generations. (A) Archetype of a CAR. The four main domains that make up a CAR are distinguished: the recognition domain, the hinge domain, the transmembrane domain, and the intracellular domain. (B) CARs generations. First-generation CARs only own the $\mathrm{CD} 3 \zeta$ in the intracellular domain; the second-generation CARs incorporate a costimulatory domain; the third-generation CARs include two costimulatory domains; and fourth-generation CARs are reinforced with genes that allow the expression of cytokines.

provides the exclusive recognition of the target molecule based on monoclonal antibodies with variable regions that are linked into a single-stranded fragment (scFv) (Shirasu and Kuroki, 2012); between the recognition and transmembrane domains lies a 2) hinge or spacer domain, which is a structure normally constructed by the flexible hinge sequences of CD8a, CD28 or the Fc region of immunoglobulins IgG1 or IgG4 (Lee et al., 2019; Roselli et al., 2019), this is in charge of bringing an effective immunological synapse (Fujiwara, et al., 2020). 3) A transmembrane domain, that is the anchor molecule to the cell membrane which impacts the regulation of the amount of CAR signaling into $\mathrm{T}$ cells via the control of the CAR surface expression level (Dwivedi et al., 2019). 4) An intracellular signaling domain, that provides the intracellular portion of the TCR invariant chain $\mathrm{CD} 3 \zeta$, which triggers the phosphorylation of the immunoreceptor tyrosine-based activation motif (ITAM's) domains activates the signaling pathway of ZAP70 (Milone et al., 2009). However, this signal is deficient to activate by itself the resting $\mathrm{T}$ cell. Hence, to improve activation, proliferation, and survival the incorporation of the costimulatory domain from other receptors, such as CD28, 4-1BB (CD137), should be included to the intracellular fragment (Ramello et al., 2019) (Figure 1A).

Simple CARs classification is given by the number of signaling groups that possess in the intracellular signaling domain, being the first-generation CARs those that in their signaling domain contain $\mathrm{CD} 3 \zeta$ chain as the primary transmitter of endogenous TCR signals (Ghosh et al., 2017). The first generation of chimeric receptors was primarily designed to mimic its $\mathrm{T}$ cell activation, a function that is sufficient to trigger cytolysis, but not enough to direct a sustained effective $\mathrm{T}$ cell response (Sadelain et al., 2009). To broaden $\mathrm{T}$ cell function, a different kind of Intracellular signaling domain was designed, mimicking a normal activation of $\mathrm{T}$ lymphocytes, and ensuring the presence of a co-stimulatory signal. Diverse co-stimulatory signals have been proposed such as CD28, 4-1BB and OX40, as they normally activate cell survival and proliferation pathways (i.e., PI3K-Akt-mTORC1) (Van Der Stegen et al., 2015). The second-generation of CARs have recently yielded impressive clinical results in patients with $\mathrm{B}$ cell malignancies, specifically in acute lymphoblastic leukemia (Brentjens et al., 2011; Maude et al., 2014). The union of two costimulatory domains in the Intracellular signaling domain is called "third-generation" CARs; this strategy increases the differentiation towards $\mathrm{T}$ cell effectors (Teff) and improves persistence by prolonging T-cell survival (Hombach et al., 2011). Further research has led to a novel generation of CARs named TRUCK cells (T-cells redirected for universal cytokine killing), also called "fourth generation" CARs that, in addition to costimulatory signal(s), is provided with a "nuclear factor of activated T cell-responsive expression" which can activate an innate immune response through the secretion of an element for an inducible transgenic product like IL-12 or another cytokine, (Figure 1B). This CAR-T is expected to be applied in fields of virus infections, auto-immune diseases, or metabolic disorders (Chmielewski et al., 2018; Date and Nair, 2021).

\section{T-Cell Procurement}

As the last element, the isolation of $\mathrm{T}$ cells is a crucial factor since these types of cells are needed to get a high-quality product. The requirements for CAR- $\mathrm{T}$ cell manufacturing process are $\mathrm{T}$ cells with $\mathrm{CD} 3 / \mathrm{CD} 4+$ and CD3/CD8+ immunophenotype. For T cell harvesting the process starts from the mononuclear cell fraction notwithstanding that the final quantities of contaminating cells are dependent upon the type of blood cell isolation process, counterflow centrifugal elutriation or even the inherent properties of the patient's blood. As a strategy for obtaining viable and high purity of $\mathrm{T}$ cells $(\mathrm{CD} 3 / \mathrm{CD} 4+$ and $\mathrm{CD} 3 / \mathrm{CD} 8+$ ) additional purification steps are needed; At this point, immunomagnetic isolation has been introduced to shift the density gradient separation (Fesnak and O'Doherty, 2017; Stroncek et al., 2017).

It has even been reported that the impact of CD4/CD8 T-cell selection on the starting apheresis product influences manufacturing feasibility, however, this strategy led to a direct increase in inflammatory toxicities (Shah et al., 2020a; Shah et al., 2020b). Clinical recommended applications of CAR-T-cell 


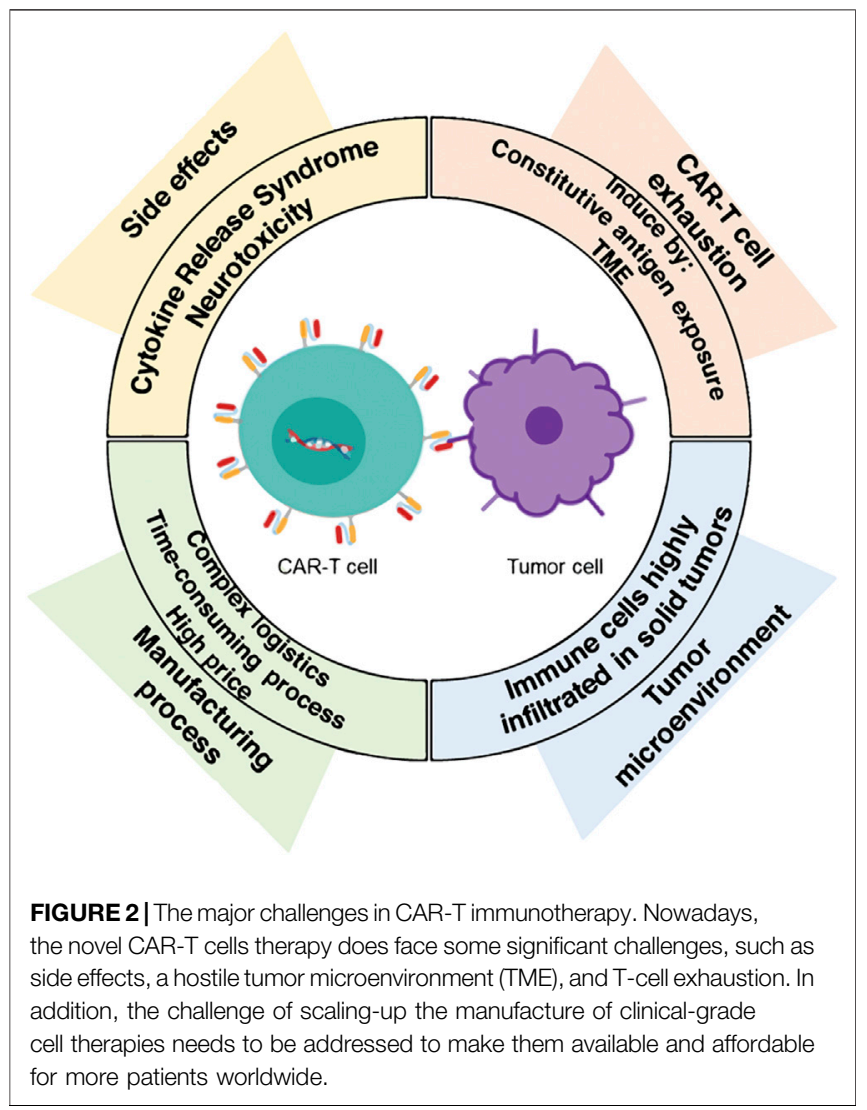

therapy include infusion products at a 2:1 ratio being approximately CD4 ${ }^{+}$CAR-T $(29 \pm 18.1 \%)$ and CD $8+$ CAR-T $(71 \pm 18.1 \%)$ (Itzhaki et al., 2020). Taking into consideration that on average one patient receives $3.1 \times 10^{6}$ transduced viable $\mathrm{T}$ cells per kilogram of body weight (range, $0.2 \times 10^{6}$ to $5.4 \times 10^{6}$ cells per kilogram) for ALL treatment. Meanwhile, for lymphoma the recommended dose of infused CAR T-cells ranged from $0.66 \times 10^{6} / \mathrm{kg}$ to $3.3 \times 10^{9} / \mathrm{m} 2$ (Maude et al., 2018; Cao et al., 2019), with a normal transduction rate around $20-60 \%$ (Itzhaki et al., 2020).

\section{Chimeric Antigen Receptor-T Cell Immunotherapy Challenges}

CAR-T cell immunotherapy has found its success where conventional therapies fail, becoming a promising emerging technology that represents an important progress for the treatment of cancer malignancies. Furthermore, it also opens new potentials for the treatment of other diseases. However, this therapy is relatively new, and some significant challenges have been observed, mainly related to side effects, toxicity, T-cell exhaustion, and hostile tumor microenvironment (TME) (Figure 2). In addition, the manufacturing process for offering clinical-grade cell therapies at a large-scale production and their distribution are currently time-consuming and costly. Therefore, making CAR-T cell immunotherapy available for as many patients as possible becomes a greater challenge. New processing techniques, quality control mechanisms and logistic developments are required to overcome these limitations and to develop robust technology. In the next paragraphs, an analysis of such challenges is presented.

\section{Side Effects and Toxicity}

After CAR-T cell infusion, close patient monitoring is a crucial part of the treatment protocol due to the potential lethal toxicities of this immunotherapy. Fever, inflammation, abnormal liver enzyme elevation, breath difficulty, chills, confusion, dizziness, lightheadedness, severe nausea, vomiting, and diarrhea are some of reported side effects. All patients have developed long-term B cell aplasia, which can be alleviated by administration of gamma globulins (Swiech et al., 2020; Zhao et al., 2020). There are two main categories of toxicity: Cytokine release Syndrome (CRS) and neurotoxicity (NTX) or CAR-T cell-related encephalopathy syndrome (CRES).

\section{Cytokine Release Syndrome}

CRS or "cytokine storm" is a systemic inflammatory response, caused by the release of inflammatory cytokines, such as IL-1, IL2, IL-6, IL-10, IL-15, interferon (IFN)- $\gamma$ and tumor necrosis factor (TNF) by a large number of activated lymphocytes (B cells, $\mathrm{T}$ cells, and/or natural killer cells) and/or myeloid cells (macrophages, dendritic cells, and monocytes) which result in a wide range of clinical symptoms including fever, fatigue, headache, rash, joint pain and myalgia (Chavez et al., 2019; Riegler et al., 2019). CRS is the most common adverse effect that occurs within a few days after the first infusion of CAR-T cells (the CRS of any grade occurred in $85 \%$ of patients). Severe CRS cases are characterized by tachycardia, hypotension, pulmonary edema, cardiac dysfunction, high fever, hypoxia, renal impairment, hepatic failure, coagulopathy, and irreversible organ damage (Park et al., 2018). Fortunately, the effects of CRS can be attenuated by reducing the number of infused T cells and/or by the administration of anti-IL- 6 receptor monoclonal antibody (tocilizumab) and steroids (Swiech et al., 2020). Nowadays, the search for different biopharmaceuticals to avoid the CRS is increasing due to COVID-19 treatment, which exhibits a similar CRS profile. This means that the next findings could be useful to improve this type of treatment.

\section{Neurotoxicity}

NTX is another common complication of CAR-T cell immunotherapy that occurs in more than $40 \%$ of patients (Belin et al., 2020). NTX described as CAR-T cell-related Encephalopathy (CRES) by Neelapu et al. (2018) and, more recently described under the name of ICANS (Immune effector Cell-Associated Neurotoxicity Syndrome) (Lee et al., 2019), is less understood than CRS and usually appears within one to 3 weeks after CAR-T cell infusion, which is frequently correlated with CRS (Siegler and Kenderian, 2020). Patients show a variety of symptoms such as confusion, obtundation, tremors, delirium, word-finding difficulty, and headaches; other symptoms such as aphasia, cranial nerve abnormalities and seizures have also been reported as part of NTX effect (Neill et al., 2020). Nowadays, neurotoxicity management is treated by 
administering tocilizumab: an IL-6 receptor antibody; systemic corticosteroids; and dexamethasone (Gust et al., 2018).

The prompt management of toxicities is essential to minimize the mortality associated with this immunotherapy, for that, researchers have developed different safety strategies for overcoming and prevent the CAR-T cells toxicities such as the design of new CARs generations (Andrea et al., 2020; Rafiq et al., 2020). Toxicity management has become a critical step in the success of CAR-T cell immunotherapy. In fact, Tmunity Therapeutics developed a dual PSMA-specific, TGF $\beta$-resistant CAR-modified autologous $\mathrm{T}$ cells (CAR-T-PSMA-TGF $\beta$ RDN) for prostate cancer with the objective to expand the use of CAR-T from hematological malignancies to solid tumors. This clinical trial (NCT04227275) had a setback that led to its winding down after two patients died from a type of ICANS. Nevertheless, the study helped to identify the potential barriers of CAR-T therapies against solid tumors, which results in a better understanding of the adverse effects mechanisms that will aid to design safer candidates.

\section{Chimeric Antigen Receptor-T Cell Exhaustion}

CAR-T cells have raised enormous interest in cancer immunotherapy due to the high rates of complete remission. Nevertheless, a large fraction of patients that achieve remission have displayed disease relapse within a few years (Maude et al., 2018; Park et al., 2018), the relapse rate varies from 21 to $45 \%$ in B-ALL and increases with the follow-up time (Cheng et al., 2019). The treatment failure could be partially explained by CAR-T cells exhaustion induced by tumor microenvironment (TME) created by solid tumors. Similar phenomena appear to extend in hematological malignancies including chronic lymphocytic leukemia (CLL), acute myeloid leukemia (AML), and diffuse large $B$ cell lymphoma (DLBCL), besides to an excessive antigen exposure (Poorebrahim et al., 2020; Shen et al., 2020). The complex and heterogeneous TME affects the activation and function of the infiltrated effector $\mathrm{T}$ cells and thus impairs the persistence, proliferation, and potential of the $\mathrm{T}$ cells rendering them exhausted (Tahmasebi et al., 2019). CAR-T cells exhaustion refers to a state of dysfunction characterized by physical deletion of antigen-specific $\mathrm{T}$ cells due to persisting antigen stimulation, the costimulatory domain of CAR structure and increased expression of inhibitory receptors, usually induced by chronic stimulation, such as cancer (Wherry, 2011; Cheng et al., 2019). In vitro CAR-T cell studies have shown that during CAR-T cell exhausting process the loss of functionality against tumors is mainly triggered by the upregulated expression of inhibitory receptors such as PD-1, Lag3, Tim3 TIGIT, and the inhibition of PI3K/AKT pathway through CTLA-4. Nonetheless, cytokines play an important role in $\mathrm{T}$ cell activity or exhaustion, for instance, CAR-T cells decrease the ability of interleukin 2 (IL-2), Tumor necrosis factor a TNF- $\alpha$, and interferon- $\gamma$ (IFN- $\gamma$ ) among other cytokines (Tang et al., 2021); Interleukin-5 (IL-5) increased proliferative capacity, decreased apoptotic state through IL-5 mediated reduction of mTORC1 activity (Alizadeh et al., 2019).

Other factors such as transcriptional factors, metabolism, and epigenetic modification also play an important role in CAR-T cell exhaustion development (Shen et al., 2020). This dysfunctional phenotype is associated with hallmarked loss of the CAR-T cell's capacity of expansion and persistence. That situation compromises the patient's clinical remission (Fry et al., 2018). The reason why CAR-T cells lose in vivo persistence and potency remains unknown (Balkhi, 2020), that is why the CAR-T cells exhaustion is a pivotal hurdle for successful CAR-T cell therapies. A possible approach to delay the exhaustion is the engineering of exhaustion-resistant CAR-T cells. Recent reports indicate that the discovery of certain transcription factors like TOX (Seo et al., 2019) and NR4A (Cheng et al., 2019), and the deletion or overexpression of AP-1 family transcription factor c-Jun (Lynn et al., 2019) increases CAR-T cell resistance to exhaustion. Some studies have shown that CAR-T cells equipped with cytokines can enhance their own lifespan and expansion, promoting their own growth and proliferation (Avanzi et al., 2018; Zhao et al., 2020). That is the reason for the TRUCKs development by genetically adding an inducible cytokine-producing cassette (e.g., IL- 12) (Zhao et al., 2020). Lately, deleting PD-1 by CAR-T cells engineering (short hairpin RNAs or CRISPR/Cas9), blocking antibodies using PD-1 and blocking the IFN- $\gamma$ signal have been used to increase the CAR-T therapy efficacy avoiding exhaustion (Cheng et al., 2019; Rafiq et al., 2020). In this case, the discovery of the cellular mechanisms involved during cell proliferation and the maintenance of cell viability are a hindrance to the functioning of this therapy.

\section{Tumor Microenvironment}

The success of CAR T-cell immunotherapy has not yet been achieved in solid tumors. A possible reason is that the immunosuppressive nature of the tumor microenvironment (TME) affects the efficacy of adoptive immunotherapy. Solid tumors are highly infiltrated with stromal cells like cancerassociated fibroblasts (CAFs) and suppressive immune cells, including myeloid-derived suppressor cells (MDSCs), tumorassociated macrophages (TAMs), tumor-associated neutrophils (TANs), mast cells, and regulatory $\mathrm{T}$ cells (Tregs) which contribute to the establishment of a hostile and immunosuppressive TME capable of interfering the efficacy of CAR-T cell therapy (Martinez and Moon, 2019; Rodriguez-Garcia et al., 2020). Strategies to overcome TME effect, include enabling $\mathrm{T}$ cells to resist tumor suppression in TME, such as transgene expression of dominant-negative receptors or signal converters, which can transform suppressive signals into stimulating signals (Tang et al., 2021). Another opportunity to overcome the persistence and exhaustion of CAR-T cells is improving the trafficking delivery of the drug to the tumor site. For CAR-T cells, local injection is a popular investigation among trials. This could be done in an anatomical cavity (pleura, peritoneum), via a device placed surgically (for CNS tumors) or via intra-arterial delivery (such as hepatic artery catheterization), or by direct intratumoral injection (Edeline et al., 2021). 


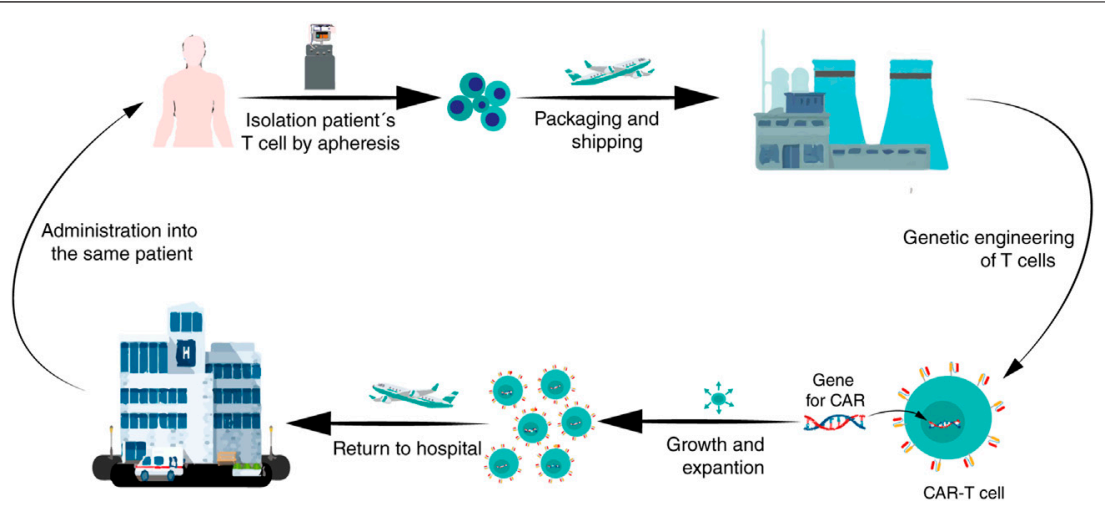

FIGURE 3 | A brief diagram of the CAR-T cells manufacturing process. After enough leukocytes have been harvested from a patient's blood via leukapheresis, T cells are shipped to a biopharmaceutical company where they are genetically engineered to express a CAR on the T cell surface. Then, the CAR-T cells are amplified in vitro; after that, the CAR-T cells are returned to the hospital for administration into the patient.

\section{Genetic Alterations}

Several reports have highlighted a lack of efficacy and relapses in patients treated with CAR-T cells (Sotillo et al., 2015; Fischer et al., 2017). Few reports have tackled the identification of genomic modifications post CAR-T cell therapy due to vector integration (Nobles et al., 2020). Orlando et al. (2018) incorporated whole-exome DNA-seq and RNA-seq to investigate the extent to which CD19 mutations are the main mechanism causing relapse. They discovered de novo CD19 genetic alterations in exons $2-5$ in 12 of 12 samples from patients, and loss-of-heterozygosity in 8 of 9 patients, concluding that homozygous mutations in CD19 are the main reason for acquired resistance to CAR-T cell therapy. Asnani et al. (2020) reported similar findings; they described skipping of exon 2 and exons 5-6 in patients with relapsed leukemia after CAR-Tc therapy. Exon 2 is essential for the integrity of CAR-T 19 epitope while exons 5-6 are responsible for the CD19 transmembrane domain (Bagashev et al., 2018). CAR-T cells have been shown to improve the efficacy of immunotherapy; however, further research is needed to explore the impact of genome analysis to identify the prognosis once CAR-T cell transfusion is performed.

\section{Manufacturing Process}

The traditional technology to manufacture CAR-T cells consists in: 1) to isolate patient's T-cells (autologous) by apheresis; 2 ) to ship recovered cells to a central manufacturing site (biopharmaceutical companies) where 3 ) they are genetically engineered to express a CAR after which 4) they are expanded in the laboratory; then, 5) the CAR-T cells are returned to a hospital to be 6) infused into the patient for tumor eradication (Figure 3) (Roddie et al., 2019). The logistics involved in this traditional manufacturing and treatment with autologous CAR-T cells adds complexity for clinicians and patients because the period in between, referred to as "vein-to-vein time", ranges between three and 4 weeks in developed countries. This period can be daunting for the patients awaiting treatment and renders the CAR-T treatment complicated for patients with rapidly progressing diseases (Aftab et al., 2020). Nowadays, this therapy presents these main manufacturing challenges and the picture in developed and underdeveloped countries is very different. Some of such challenges include:

\section{Packaging, Shipping, and Storage of Chimeric Antigen Receptor-T Cells}

The clinical manufacture of CAR-T cells is currently a complex process that involves several steps across different geographic locations with multi-technologies and logistics. Any error in timing, transportation methods, cold chain, or storage, would result in cell damage directly impacting therapy efficiency, hence each one of the steps requires careful management, precise sample tracking and adequate preservation technologies to either freeze or cryopreserve patient samples (Papathanasiou et al., 2020). Different shipments with dissimilar temperatures are required throughout the CAR-T cell manufacturing process, therefore, suitable cryopreservation during production is mandatory for quality control tests (Stock et al., 2019).

\section{Current Good Manufacturing Practices}

CAR-T cells have a complex preparation process and the cGMP's are a critical and a bottleneck in CAR-T cell production (Wang and Rivière, 2016). The aim of cGMP's is to provide a framework to ensure high-quality production in well-controlled facilities and equipment by well-trained and regularly trained staff. Likewise, it provides strict documentation processes that covers all operation aspects to demonstrate a continuous and adequate compliance (Li et al., 2019). The CAR-T cells manufactured under GMP regulations should provide a system in which the cells will be prepared under controlled, auditable, reproducible conditions that result in providing adequate evidence of identity, safety, purity, and potency (Gee, 2018). The manufacturing protocols must improve reproducibility, cost-effectiveness, and scalability that will enable a broad application of CAR-T cell therapies (Fernández et al., 2019). According to International Organization for Standardization (ISO)5 CAR-T cell manufacturing requires GMP facilities as cell processing clean rooms, that must be equipped with 1) Facilities systems (e.g., air-handlers, 24/7 alarm monitoring systems); 2) Environmental monitoring 
equipment (e.g., viable and nonviable particle counters); 3) Manufacturing process equipment (e.g., cell washers, bioreactors); and 4) Analytical equipment (e.g., automatic cell counters, flow cytometers) (Wang and Rivière, 2016). To optimize the GMP facilities the use of automatized manufacturing processes as CliniMACS or Cocoon is feasible to achieve reproducible processes in a closed system. Another key to maintaining a compliant GMP manufacturing environment is the highly skilled staff with extensive knowledge of GMP manufacturing, quality control, and quality assurance (Wang and Rivière, 2016). One complete review of the requirements for CTL019 is presented by Levine et al. (2017), who explain the complete manufacturing process and the challenges involved in each stage.

\section{Production of Lentiviral Vectors}

The approval of LV gene therapy products (e.g., Kymriah/ Novartis) increased their demand and has created the need to improve their large-scale manufacture to clinical-grade LV (Lester et al., 2018). Nevertheless, the LVs production has challenges, such as their inherent cytotoxicity, low stability, and the dependency on transient transfection impact, both upstream and downstream processes that are reflected in low yielding and cost-ineffective compared to another viral vector (Ferreira et al., 2021). The level of GMP compliance required for the manufacture of LV is a combination of diverse factors including regulatory expertise, compliant facilities, validated and calibrated equipment, starting materials of the highest quality, trained production personnel, scientifically robust production processes, and quality by design approach (Levine et al., 2017; Dasgupta, et al., 2020). In addition, part of the commercialization success of this gene therapy product is the establishment, standardization, and implementation of stable cell lines to produce LVs facilitating GMP-compliant processes, providing an easier scale-up, reproducibility, biosafety, and cost-effectiveness (Ferreira et al., 2021).

\section{Staff and Training}

Considering the complex nature of the therapy and its associated high-risk side effects, access to CAR-T cells is highly regulated, making them available only at certified centers and administered by trained staff. All staff involved in CAR-T cell manufacturing (from $\mathrm{T}$ cell collection to the manufacturer and back to the clinical unit) require a broad training with satisfactory levels of competency. Such abilities manage complications that could arise during the process hence being able to deliver the product (Yakoub-Agha et al., 2020). Nowadays, there are only a few prepared professionals in this field, however, multidisciplinary collaboration is needed to create greater knowledge in this area. Academic participation is an important fact because the new personnel need to acquire different abilities to manufacture CART cells.

\section{Quality Control}

As a living "drug," a CAR-T cell has a complex preparation process and requires "whole-process quality control". During the production, well-controlled cold chain transport and storage play

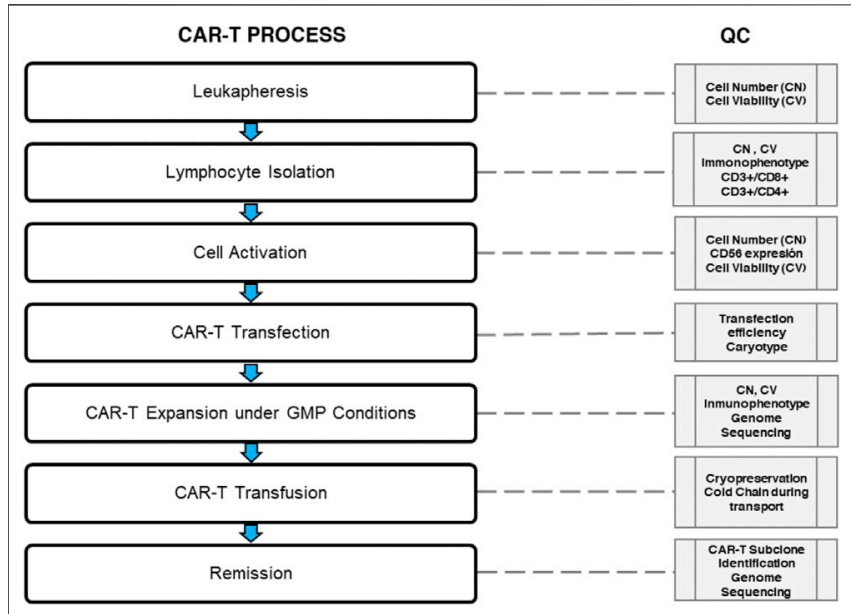

FIGURE 4 | Quality control during CAR-T cell therapy. The median of total nucleated cells (TNC) is $98 \times 10^{8}$ (range $9-341 \times 10^{8}$ ) with a viability analysis of $98 \%$ for quality control $(\mathrm{QC})$ in the leukapheresis products. However, the QC could be set in $10 \times 10^{8} \mathrm{CD}^{+} \mathrm{T}$ cells with a viability analysis of $98 \%$ (99.6-100\%) in a median volume of $237 \mathrm{ml}$ (136-310 $\mathrm{ml}$ ) for $\mathrm{CD}^{+} \mathrm{T}$ cell isolation (Data based in the report of Korell et al., 2020). The normal transduction rate is around $20-60 \%$ using lentiviral vectors. A 2:1 ratio immunophenotype of CD4+: CAR-T $(29 \pm 18.1 \%)$ and CD8+: CAR-T (71 \pm $18.1 \%$ ) is recommended for clonal CAR-T cell expansion under GMP conditions. Clonal expansion must reach $3.1 \times 10^{6}$ transduced viable T cells per kilogram of body weight (range, $0.2 \times 10^{6}$ to $5.4 \times 10^{6}$ cells per kilogram); this CAR-T cells product is ready for cryopreservation. Cold chain must be controlled during transportation using liquid nitrogen. Prior infusion lymphodepleting chemotherapy with fludarabine and cyclophosphamide it is used. Finally, rate a CAR-T subclone identification followed by genome sequency should be evaluated for measure the molecular remission.

an important role in ensuring the cell products' quality and preventing the bacteria and mycoplasma contamination (Li et al., 2019). Current requirements in the CAR-T cell's quality control include the inspection of ex vivo transduced $\mathrm{T}$-cell for the replicative virus and of the production materials. Furthermore, it should include a release test of the finished products to confirm identity, purity, safety, and potency, considering CAR-T cell's characteristics as biological products, cell products, and gene therapy products (Figure 4) (Eyles et al., 2019; Li et al., 2019). In addition, the validation of the production process is essential for CAR-T cells to be considered a final product. Moreover, stability studies are needed to verify the storage conditions and their shelf life. Besides, the production of CAR-T cells needs more in-depth studies to evaluate T cells' quality in both relapsed and regression patients. These studies should provide data about the distribution of lymphocyte populations. This information can guarantee efficient cell transduction and propagation ensuring the CART cells' quality, and subsequently it would be reflected in the decrease of CAR-T cells exhaustion in patients. To sum up, quality control is of ultimate importance for the success of CAR-T therapy (Dai et al., 2019).

\section{Scaling Up}

CAR-T cells manufacturing should be scalable (that means, to have many single bioreactors for each patient) to have a broader 
scope to benefit patients without sacrificing the quality and reproducibility of the products (Dai et al., 2019). Personalized therapies such as autologous cell-therapies require an "intensive scale-up", that is related to the fact of having many bioreactors to amplify the CAR-T cells for each patient, instead of increasing the volume as in common biopharmaceuticals. Besides, it depends upon the ability to accommodate multiple independent productions in parallel (Wang and Rivière, 2016).

\section{Limited Opportunity for Redosing}

CAR-T cells manufacturing does not allow volumetric scale-up, consequently, cells must be prepared as a single batch limiting the quantity of available product. Under this scenario, patients may not have the opportunity to receive a new infusion of their CAR-T cells quickly and easily if needed (Aftab et al., 2020; Papathanasiou et al., 2020).

\section{Time Manufacturing}

CAR-T cells can take up to 4 weeks to manufacture, during this window of time, the patients are extremely vulnerable with risk of disease progression and mortality while waiting for infusion (Rafiq et al., 2020). Nevertheless, the use of novel strategies could help to overcome such a limitation, but it is necessary to consider the time required for transporting to prepare the adequate conditions for the patient. This takes around 6 weeks for the treatment to be applied at best.

\section{Pricing and Patient Access}

Pricing and patient access is the most important limitation to overcome to disclose the use of CAR-T cells all over the world. The current model of CAR-T cell manufacturing is highly centralized: firstly, the patient's $\mathrm{T}$ cells must be transported (often internationally) to the manufacturing facility, secondly, the CAR-T product is returned to the patient for infusion (Hay and Cheung, 2019). The process is complex in each step, resulting in highly costly therapy that ranges between $\$ 373,000$ and $\$ 475,000$ USD per treatment (hospital expenses associated with the therapy are not considered in such average costs) that neither patients nor the health-care system can afford. This prohibitive cost and the reimbursement gap limit the patient's access and remain unsustainable in socio-economically underdeveloped countries, restricting even more the widespread use of CAR-T cell therapies. Until CAR-T cell therapy becomes affordable, its potential will remain untapped (Yadav et al., 2020).

\section{Regulatory Requirements}

Another important bottleneck in cellular products is regulation. The CAR-T cells are globally considered within Advanced Therapy Medicinal Products (ATMP) and these products require licensure (Marks 2019). Regulatory agencies are highly related to standard therapies, but cellular products have special requirements. US or EU regulatory authorities are working to define optimal guidelines that can globally harmonize the requirements for clinical manufacturing of ATMP (Kaiser et al., 2015). Meanwhile underdeveloped countries face a greater challenge because CAR-T therapeutic use in clinics is hugely restricted, resulting in a poor understanding of the regulatory requirements by the authorities.

\section{Strategies to Increase the Use of Chimeric Antigen Receptor-T Cells Technology. Discovery of New Biomarkers}

Biomarkers are of main importance for cancer clinical management, as they can be used to define the criteria to identify the patients suitable for CAR-T therapy, prognosis, prediction of response to treatment and monitoring disease progression. Developing cancer immunotherapy has therapeutic implications and its success varies depending on the type of cancers (Schumacher et al., 2015). On the other hand, CAR-T cell immunotherapy has achieved promising results mainly in patients with hematologic malignancies. On the other side, this type of therapy has more obstacles attacking solid tumors, including immunosuppressive tumor microenvironment (TME), lack of permeation of the CAR-T cells into tumors, limited transport, and specific tumor antigen (Ling, 2020). Despite the significant advances, clinical improvement after CAR-T therapy has not been observed for all the patients who have undergone this immunotherapy. Such differences could rely on molecular response; hence it is necessary to fully understand remission and relapse in CAR-T therapy through biomarkers. Consequently, it is essential to identify the clinical features in the form of biomarkers that drive response, resistance, and adverse effects because of immunotherapies (Townsend et al., 2018). Thus, for the respective CAR-T cell immunotherapy development and success it is essential to broaden the range of cancers that respond to such a kind of immunotherapy with the discovery of new biomarkers. The identification of new biomarkers improves clinical practices for early recognition and minimization of adverse effects while preserving the antitumor activity of the CAR-T cells (Mirzaei et al., 2018), it opens the possibility to target other types of tumors and leads to the development of new strategies for numerous types of cancer treatments, positioning CAR-T cells as a therapeutic option in cancer medicine (Ponterio et al., 2020). The first biomarker for CAR-T - therapy was CD19, a B cell surface protein expressed mainly on malignant B cells. Currently, scientific research is underway to find out biomarkers according to the stage of immunotherapy as follows: biomarkers to define patients baseline status; biomarkers for CAR-T-cell function, CAR-T cell exhaustion, CAR-T cell toxicity and biomarkers for cancer prognosis, response, and relapse (Mirzaei et al., 2018). As for baseline biomarkers, cytokines of the immune system such as IL2, IL-5, IL-7, TNF-a, among others; lactate de Lactate dehydrogenase (LDH) and CD9 cells, are widely used. Meanwhile, for CAR-T cell function, the following biomarkers have been proposed: CD45RA, CD45RO, CD62L, CCR7, CD27, CD28 (differentiation markers), CD25, CD127, CD57, and CD137 (activation markers) (Wang et al., 2019; Hong et al., 2021). Currently, there are no proven biomarkers that can be used to assess CAR-T cell exhaustion after infusion in patients. However, indirect parameters could be helpful for this purpose; for example, a sustained gain in B-cell recovery 
within 3 months after CART-therapy and the detection of LAG3+ cells could be considered due to CAR-T cell exhaustion. As well as high levels of expression of PD-1, LAG-3, TIM-3, and their receptors are associated with $\mathrm{T}$ cell exhaustion and poor response to CD19 CAR-T therapy (Hong et al., 2021). Recently a model of $\mathrm{T}$ cell exhaustion assessment through flow cytometry has been proposed based upon PD-1 pathway blockade response, identifying three main stages: exhausted progenitors, intermediated exhausted, and terminally exhausted T cells (Beltra et al., 2020). Relapse: IL-6, Protein C reactive, TNF-a, serum calcium, serum phosphate, uric acid (Zhang et al., 2016). In Table 3, a summary of novel target antigens selection for CAR-T cells in hematologic malignancies and solid tumors under clinical trials is presented. Despite significant advances in CAR-T therapy, it is essential to continue exploring different cancer cell-type-specific biomarkers to develop more specific therapies.

\section{Allogeneic Chimeric Antigen Receptor-T Cells}

Currently, most CAR-T cell immunotherapy is generated using autologous $\mathrm{T}$ cells. This represents several disadvantages at different levels. For example, autologous cell therapy is performed for individual patients, the production can be longtime consuming and complicated, resulting in the increase of costs and it can limit the broader application of this therapy. In addition, the challenges due to the use of patient-derived $\mathrm{T}$ cells for CAR therapy include weaker proliferation, limited expansion, and low persistence of CAR-T cells. In some cases, CAR-T cell efficacy, most likely due to poor autologous immune cell strength in cancer patients caused by aggressive treatments (Caldwell et al., 2021). One opportunity for improving some manufacturingrelated issues is the use of allogeneic CAR-T cells for reducing time delays on autologous cell production. Generating universal CAR-T cells from allogeneic healthy donors could set the stage for overcoming high costs and high time production, making them easily available and with higher quality. Such a fact is very important for patients with aggressive cancers that require urgent therapy (Caldwell et al., 2021). This strategy would broaden the number of patients that could receive this immunotherapy to make CAR-T cell therapy an off-the-shelf treatment at an affordable cost, that be readily available and would increase quality properties in T cells (Cheng et al., 2019). Another advantage is that universal CAR-T cells could provide the possibility of manufacturing clinical-grade CAR-T products against various cancers "on-demand" (Balkhi, 2020). However, it is important to also consider the up-coming challenges and disadvantages for using universal CAR-T cells. For example, immunologic mismatch between donor and recipient, if the administered allogeneic $T$ cells attack healthy recipient tissues, may cause life-threatening graft-versus-host disease (GVHD), and if the recipient's immune system recognizes and reacts against the allogeneic $\mathrm{T}$ cells, these may be rapidly eliminated by the host immune system limiting the expected therapeutic effect (Depil et al., 2020). A possible solution is a genetic elimination or disruption of the TCR gene and/or HLA class I loci on the donor to eliminate GVHD (Cheng et al., 2019), also, the use of allogeneic anti-CD19 CAR with deleted $\alpha$-TCR chain and CD52 gene loci has demonstrated effectiveness to eliminate GVHD (Cheng et al., 2019; Balkhi, 2020).

Different allogeneic strategies have appeared to improve immunotherapy challenges such as the use of induced pluripotent stem cells (iPSC). iPSCs offer the opportunity to be unlimitedly cultured in vitro and be successfully differentiated towards the lymphoid lineage as to NK lymphocytes that are innate lymphocytes that kill malignant cells in an HLAindependent manner (Kennedy et al., 2012). The use of iPSCs provides unlimited "off-the-shelf" NK cells offering doses without limitations, standardized and cost-effective products (Zeng et al., 2017). iPSCs can generate immune effectors with the capacity of easily being genetically modified to augment their applicability, potency, and persistence (Nianias and Themeli, 2019). The possibility of effortlessly generating NK cells from iPSCs (iPSC-derived NK cells) opens the great option to use the CAR constructions as an alternative to $\mathrm{T}$ cells, to produce CARiPSCNK cells with rapid responses against malignant cells without causing GVHDs (Euchner et al., 2021). Compared to CAR-T cells, CAR-NK cells offer some more advantages, such as a lack or a decrease in cytokine release syndrome and neurotoxicity in an autologous setting, another point in its favor is the multiple mechanisms for activating cytotoxic activity (NKG2D, KIR's, CD16, NKp30, NKp44, NKp46), still maintaining its infiltration capacity into solid tumors and into the resistant tumor microenvironment (Xie et al., 2020). CAR-NK preclinical studies showed effectiveness against hematologic malignancy targets (CD19 and CD20), as well as solid tumor targets demonstrating their potential to be an allogeneic therapeutic (Caldwell et al., 2021). Besides CAR-iPSCNK strategy, virus-specific $\mathrm{T}$ cells, memory $\mathrm{T}$ cells, genetically modified $\alpha \beta \mathrm{T}$ cells, and $\gamma \delta \mathrm{T}$ cells are other effective ways to tackle allogeneic CAR immunotherapy. All these strategies have in common their effectiveness to attack malignant cells, and the possibility to use CAR construction to improve toxicity effects, costs and efficiency of CAR-T manufacturing, and the persistence of reducing GVHD risk (Martinez and Moon, 2019; Yazdanifar et al., 2020).

\section{Other Strategies to Improve Chimeric Antigen Receptor-T Cells Outcomes}

Dual or tandem CARs, consist of the coexpression of two separate CARs in each $T$ cell, which recognize two different antigens rather than one. Some dual CARs have entered clinical trials in hematological malignancies targeting CD19/CD20, and CD19/ CD22 (Zah et al., 2016; NCT03241940) and solid tumors. CAR specific for HER2/MUC1 had promising in vitro results in a breast cancer model. It is important to mention that dual-target CAR specific HER2/IL13Ra2 showed greater success than singletarget CARs in a xenograft glioma model (Martinez and Moon, 2019). Dual CAR is a promising method to address antigen heterogeneity and to prevent the relapse caused by antigen escape (Huang et al., 2020). Synthetic Notch (synNotch) receptors have been applied in CAR-T cells to improve safety. SynNotch receptors recognize one specific tumor antigen and 
then transcriptional activation domains are released, promoting the local expression of a CAR (Han et al., 2019). Moreover, synNotch-regulated CAR expression prevents constitutive signaling and exhaustion, maintaining a higher fraction of the $\mathrm{T}$ cells in a naïve/stem cell memory state (Choe et al., 2021). Synthetic Notch (synNotch) receptors have been applied in CAR$\mathrm{T}$ cells to improve safety. SynNotch receptors recognized one specific tumor antigen and then transcriptional activation domains were released, promoting the local expression of a CAR (Han et al., 2021). Moreover, synNotch-regulated CAR expression prevents constitutive signaling and exhaustion, maintaining a higher fraction of the $\mathrm{T}$ cells in a naïve/stem cell memory state (Choe et al., 2021). Inhibitory chimeric antigen receptor (iCAR), which incorporates inhibitor receptors, such as $\mathrm{PD}-1$ and CTLA-4, play a crucial role in attenuating or terminating $\mathrm{T}$ cells response, therefore, they are considered a safety strategy (Yu et al., 2019). iCAR shows antigenspecific suppression of T cell cytokine secretion, cytotoxicity, and proliferation of rapid and selective kills of target cells that only express one antigen, whereas off-target cells, that co-expresses another inhibitory ligand recognized by iCAR, are protected from attack. This allows $\mathrm{T}$ cells to distinguish target cells from the offtarget cells (Han et al., 2019). With this said, it is important to highlight the following aspects for a successful clinical application: the iCARs' affinity and expression level, the appropriate selection of target antigen and the optimization of the CAR/iCAR ratio (Gargett and Brown, 2014). Currently, Jan and cols., have developed ON and OFF switches for CAR-T cells using lenalidomide, a clinically approved drug, which facilitates the proteasome degradation of several target proteins (Jan et al., 2021). In addition, to efficiently treat solid tumor, innovative combinations strategies such as vaccines, biomaterials, and oncolytic virus are good prospects, because they allow either to directly enhance $\mathrm{T}$ cells' function or to recruit endogenous immune cells as well as remodeling the TME (Huang et al., 2020).

\section{Fully Automated Manufacturing Process}

Worldwide, the number of patients who require CAR-T cell immunotherapy quickly increases. That is the reason why the standardization of the manufacturing process (following GMP's), the quality control and expanding the production to hospitals making the treatment accessible for a larger number of patients, are highly needed. The industry has developed automated and closed cell manufacturing platforms to adapt to this scenario. Examples of this effort are the automatized platforms Cocoon $^{\circledR}$ (Lonza) and CliniMACS Prodigy (Miltenyi Biotec), both allow reproducible and rapid production of cells, and every step is strictly documented. Cocoon $^{\circledR}$ Platform streamlines patient-scale cell therapy manufacturing making them more efficient, reliable, and flexible. These features speed up CAR-T manufacturing, cut costs and decrease manufacturing failure rates that may be associated with more hands-on methods. In 2020 Lonza and Sheba Medical Center announced the first patient has been treated at Sheba Medical Center with CD19 CAR-T cell immunotherapy manufactured using Lonza's Cocoon Platform. Another example for automated and supervised manufacturing is CliniMACS, which allows $\mathrm{T}$ cell activation, transduction, amplification, and final harvesting of CAR-T cells, with high transduction frequencies and high cell numbers in the same device. This method fully controls the multi-step process through a flexible programming suite (Lock et al., 2017; Köhl et al., 2018).

\section{Network Collaboration}

Unfortunately, most of the patients cannot afford CAR-T therapy due to the high costs and the lack of facilities around the world to produce them. The efforts focused on quality production following the GMP's had been successful to a certain extent, but the road is still long to bring this technology to a massive application.

To achieve this, it is necessary to generate a collaborative network between various stakeholders such as the academia, the industry, and the hospitals, for the establishment of adequate and robust legislation for this type of product in each country where such a technology is applied. Thus, universities should provide knowledge and innovation to future professionals for them to do research on new biomarkers discoveries, on the development of stable cell lines, and on developing and validating orthogonal analysis methodologies for the product quality and for them to learn about different production systems. The industry applying GMP's, quality control and automation processes can support the establishment of more standardized and reliable products that have a high quality, and it can also develop on-site production units that allow lower transport and storage costs. Hospitals must have adequate facilities for the management of this technology, with trained personnel in the management of production units in situ (if applicable), as well as medical personnel and health professionals for the effective treatment of patients. Encompassing all these activities there must be robust and specific legislation in this area that guarantees the quality of this type of advanced therapy. Additionally, regulation is an essential part of such a process. Nowadays, there is sparse information about regulatory guidelines in different countries, the EMA and FDA guidelines (Iglesias-López et al., 2019) have established the baseline of such requirements for these technologies but the behavior and results on different phases of clinical trials will address novel considerations. One challenge but at the same time one opportunity will be to establish local regulation of these technologies in every country that needs to be approved by competent authorities for smooth implementation of CAR-T cell clinical programs. All this collaborative effort is the key to allow worldwide access to CAR-T cell therapy to a larger number of individuals with cancer.

Finally, the idea of promoting the use of CAR-T cells technology in a greater number of countries rests on its potential application in various diseases in both adults and children. To our knowledge, the application of CAR-T cells technology has been mainly used in developed countries (Elahi et al., 2018), revealing a large gap in the rest of the world. In fact, the only clinical study conducted in Latin America was made in Brazil (Cunha Oct 16, 2019) in a 63-year-old man that was affected by BLBCL. Therefore, it is important to consider that for this technology to be enforceable in developing countries various policies must be created and implemented. On the one hand, technology transfer agreements can be established among centers with experience in the subject and treatment centers in 
developing countries, however, this continues to foster scientifictechnological dependence. On the other hand, developing countries should work on integrating their own elements (academy-industryhospital and government), generating treatments of this type but geared to the specific needs of its population and adapting them to the available resources. However, it is important to highlight that in this case, government support is essential to start setting up treatment centers for advanced therapies in hospitals and health institutions. In addition, international support from non-profit institutions in terms of financial resources and support for the training of professionals is also necessary.

\section{DISCUSSION}

Current and widely used methods for cancer treatment consist of surgery, chemotherapy, radiation therapy and immunotherapy (mainly monoclonal antibodies). Despite the health care system efforts, with the increasing incidence of cancer, its clinical management continues to be a major challenge. Recently, remarkable progress has been achieved towards adoptive immunotherapies through clinical application and consistent evolution of ACT strategies. Such immunotherapies, in combination with conventional methods have proven major efficiency for cancer treatment. In the last few years, CAR-T cell therapy, a type of ACT, has demonstrated potential in clinical trials, leading to complete and durable responses in patients with late-stage and treatment-refractory disease. In fact, there are currently 5 FDA-approved products on the market, which have been tested in a few hundred patients during clinical trials in developed countries around the world. Furthermore, the first one was approved for commercial use in 2017 but the cost of such a treatment is substantially high (from $\$ 375,000.00$ to $\$ 475,000.00$ without considering operation and indirect costs) so, considering its potential application in the treatment of different types of diseases there is a need to improve the technology to make it more accessible to the world's population.

From a pharmaceutical point of view, CAR-T cells are considered as advanced therapy products or biopharmaceuticals (depending on the country) whose quality must be demonstrated through their identity, safety, and efficacy. This novel technology is the set of synergy between three main elements: the targets (antigens against the CAR will be directed and that, ideally, are required to be only expressed in malignant cells); chimeric receptors (whose sophistication allow to bind to said antigen and that are designed to provide better selectivity towards tumor cells, and properly, T cells (containing $\mathrm{CD} 3+/ \mathrm{CD} 4+$ and $\mathrm{CD} 3+/ \mathrm{CD} 8+$, in an adequate proportion) that are genetically modified to express the CAR and guarantee the success of such therapy.

Each of the previous three elements presents significant challenges. As discussed in this work, the search for biomarkers is an exhaustive task aimed at identifying target molecules that are specific to a certain type of disease, which will help improve efficacy and reduce adverse effects. Likewise, the improvement in the development of CARs to promote an effective union with the receptor and the generation of an effective immune response against the disease and improve activation, proliferation, and survival is the subject of study. Furthermore, many efforts are directed at the selection of the $\mathrm{T}$ cells used in this technology, such cells must comply with adequate phenotypic characteristics; being genetically stable; being able to transduce within a high percentage (also putting on the table the need of vector optimization for this purpose); being expanded to reach the required levels for the therapy; being enough stable to avoid the cell exhaustion; and, accomplishing all the requirements of a cell therapy product at the level of identity, purity and efficacy. Furthermore, it is necessary to focus on the reduction of adverse effects related to CRS and NTX and in the application of this technology in solid tumors with the idea of increasing the safety and efficacy of this therapy, among other points of improvement.

Alternatively, the need to generate lower-cost production systems, with robust production in each batch (patient-specific), but that meet the necessary quality requirements to be applied to the patient is also a constant challenge. Currently, the use of automated systems applicable in situ seems a promising alternative. These processes must be in complete harmony with the requirements established by international and regional health authorities.

Finally, considering all the aspects of this therapy, the multidisciplinary participation of health care professionals in various stages is required. Through intensive collaborations between academia, industry, hospitals, and government, both at the international and regional level, it will be possible to achieve a broader accessibility to this technology to a larger number of patients. This situation should be able to overlap in the case of developing countries, who must seek different strategies by applying their own generated knowledge, making an efficient use of the existing infrastructure, and seeking collaborations at various levels to obtain the necessary information and resources. The implementation of these strategies is likely to increase the number of treatments all over the world.

\section{AUTHOR CONTRIBUTIONS}

All authors conceptualized, designed, and assisted with the draft/ approval of this manuscript.

\section{FUNDING}

The financial support for this work was by I0031-201903MACROPRONAII-SALUD-2019 Programa Nacional Estratégico para la Leucemia Infantil, CONACYT postdoctoral fellowship to AH-L (CVU: 253979), CONACYT INFR-2014 226271 and CONACYT doctoral fellowship to MA T-G (02986).

\section{ACKNOWLEDGMENTS}

We gratefully acknowledge Facultad de Farmacia, Universidad Autónoma del Estado de Morelos. AH-L (CVU: 253979) is the recipient of a postdoctoral fellowship from CONACYT during development of this work. 


\section{REFERENCES}

Aftab, B. T., Sasu, B., Krishnamurthy, J., Gschweng, E., Alcazer, V., and Depil, S. (2020). Toward "Off-The-Shelf" Allogeneic CAR T Cells. Adv. Cel Gene Ther 3, 1-11. doi:10.1002/acg2.86

Al-Juhaishi, T., and Ahmed, S. (2021). Selecting the Optimal CAR-T for the Treatment of B-Cell Malignancies. Curr. Hematol. Malig Rep. 16, 32-39. doi:10.1007/s11899-021-00615-7

Albinger, N., Hartmann, J., and Ullrich, E. (2021). Current Status and Perspective of CAR-T and CAR-NK Cell Therapy Trials in Germany. Gene Ther., 1-15. doi:10.1038/s41434-021-00246-w

Alizadeh, D., Wong, R. A., Yang, X., Wang, D., Pecoraro, J. R., Kuo, C. F., et al. (2019). IL15 Enhances CAR-T Cell Antitumor Activity by Reducing mTORC1 Activity and Preserving Their Stem Cell Memory Phenotype. Cancer Immunol. Res. 7, 759-772. doi:10.1158/2326-6066.CIR-18-0466

Andrea, A. E., Chiron, A., Bessoles, S., and Hacein-Bey-abina, S. (2020). Engineering Next-Generation Car-T Cells for Better Toxicity Management. Int. J. Mol. Sci. 21, 1-25. doi:10.3390/ijms 21228620

Anelone, A. J. N., Villa-Tamayo, M. F., and Rivadeneira, P. S. (2020). Oncolytic Virus Therapy Benefits from Control Theory. R. Soc. Open Sci. 7 (7), 200473. doi:10.1098/rsos.200473

Arruebo, M., Vilaboa, N., Sáez-Gutierrez, B., Lambea, J., Tres, A., Valladares, M., et al. (2011). Assessment of the Evolution of Cancer Treatment Therapies. Cancers (Basel) 3, 3279-3330. doi:10.3390/cancers3033279

Asnani, M., Hayer, K. E., Naqvi, A. S., Zheng, S., Yang, S. Y., Oldridge, D., et al. (2020). Retention of CD19 Intron 2 Contributes to CART-19 Resistance in Leukemias with Subclonal Frameshift Mutations in CD19. Leukemia 34, 1202-1207. doi:10.1038/s41375-019-0580-z

Avanzi, M. P., Yeku, O., Li, X., Wijewarnasuriya, D. P., van Leeuwen, D. G., ParkCheung, H, et al. (2018). Engineered Tumor-Targeted T Cells Mediate Enhanced Anti-tumor Efficacy Both Directly and through Activation of the Endogenous Immune System. Cell Rep 23, 2130-2141. doi:10.1016/ j.celrep.2018.04.051

Bagashev, A., Sotillo, E., Tang, C. H., Black, K. L., Perazzelli, J., Seeholzer, S. H., et al. (2018). CD19 Alterations Emerging after CD19-Directed Immunotherapy Cause Retention of the Misfolded Protein in the Endoplasmic Reticulum. Mol. Cel Biol. 38, e00383-18. doi:10.1128/MCB.00383-18

Balkhi, M. Y. (2020). Challenges and Opportunities to Improve CAR T-Cell Therapy. Basics Chimeric Antigen Recept. Immunother. 63, 63-80. doi:10.1016/b978-0-12-819573-4.00005-3

Bamdad, C., Stewart, A. K., Smagghe, B. J., Glennie, N. D., Huang, P., Moe, S., et al. (2019). First-in-human CAR $\mathrm{T}$ for Solid Tumors Targets the MUC1 Transmembrane Cleavage Product. Cytotherapy 21 (5), S9. doi:10.1016/ j.jcyt.2019.03.563

Belin, C., Devic, P., Ayrignac, X., Dos Santos, A., Paix, A., Sirven-Villaros, L., et al. (2020). Description of Neurotoxicity in a Series of Patients Treated with CAR T-Cell Therapy. Sci. Rep. 10, 18997. doi:10.1038/s41598-020-76055-9

Beltra, J. C., Manne, S., Abdel-Hakeem, M. S., Kurachi, M., Giles, J. R., Chen, Z., et al. (2020). Developmental Relationships of Four Exhausted CD8+ T Cell Subsets Reveals Underlying Transcriptional and Epigenetic Landscape Control Mechanisms. Immunity 52, 825-841. doi:10.1016/j.immuni.2020.04.014

Berraondo, P., Sanmamed, M. F., Ochoa, M. C., Etxeberria, I., Aznar, M. A., PérezGracia, J. L., et al. (2019). Cytokines in Clinical Cancer Immunotherapy. Br. J. Cancer 120 (1), 6-15. doi:10.1038/s41416-018-0328-y

Berrón-Ruíz, L., López-Herrera, G., Ávalos-Martínez, C. E., Valenzuela-Ponce, C., Ramírez-SanJuan, E., Santoyo-Sánchez, G., et al. (2016). Variations of B Cell Subpopulations in Peripheral Blood of Healthy Mexican Population According to Age: Relevance for Diagnosis of Primary Immunodeficiencies. Allergol. Immunopathol (Madr) 44, 571-579. doi:10.1016/j.aller.2016.05.003

Bouchkouj, N., Kasamon, Y. L., de Claro, R. A., George, B., Lin, X., Lee, S., et al. (2019). FDA Approval Summary: Axicabtagene Ciloleucel for Relapsed or Refractory Large B-Cell Lymphoma. Clin. Cancer Res. 25, 1702-1708. doi:10.1158/1078-0432.CCR-18-2743

Bray, F., Ferlay, J., Soerjomataram, I., Siegel, R. L., Torre, L. A., and Jemal, A. (2018). Global Cancer Statistics 2018: GLOBOCAN Estimates of Incidence and Mortality Worldwide for 36 Cancers in 185 Countries. CA Cancer J. Clin. 68, 394-424. doi:10.3322/caac.21492
Brentjens, R. J., Davila, M. L., Riviere, I., Park, J., Wang, X., Cowell, L. G., et al. (2013). CD19-targeted T Cells Rapidly Induce Molecular Remissions in Adults with Chemotherapy-Refractory Acute Lymphoblastic Leukemia. Sci. Transl. Med. 5, 177ra38. doi:10.1126/scitranslmed.3005930

Brentjens, R. J., Rivière, I., Park, J. H., Davila, M. L., Wang, X., Stefanski, J., et al. (2011). Safety and Persistence of Adoptively Transferred Autologous CD19Targeted T Cells in Patients with Relapsed or Chemotherapy Refractory B-Cell Leukemias. Blood 118 (18), 4817-4828. doi:10.1182/blood-2011-04348540

Brown, C. E., and Mackall, C. L. (2019). CAR T Cell Therapy: Inroads to Response and Resistance. Nat. Rev. Immunol. 19 (2), 73-74. doi:10.1038/s41577-0180119-y

Caldwell, K. J., Gottschalk, S., and Talleur, A. C. (2021). Allogeneic CAR Cell Therapy-More Than a Pipe Dream. Front. Immunol. 11, 1-12. doi:10.3389/ fimmu.2020.618427

Cao, G., Lei, L., and Zhu, X. (2019). Efficiency and Safety of Autologous Chimeric Antigen Receptor T-Cells Therapy Used for Patients with Lymphoma: A Systematic Review and Meta-Analysis. Medicine (Baltimore) 98, el7506. doi:10.1097/MD.0000000000017506

Castella, M., Caballero-Baños, M., Ortiz-Maldonado, V., González-Navarro, E. A., Suñé, G., Antoñana-Vidósola, A., et al. (2020). Point-of-care CAR T-Cell Production (ARI-0001) Using a Closed Semi-automatic Bioreactor: Experience from an Academic Phase I Clinical Trial. Front. Immunol. 11, 482. doi:10.3389/fimmu.2020.00482

Charmsaz, S., Collins, D. M., Perry, A. S., and Prencipe, M. (2019). Novel Strategies for Cancer Treatment: Highlights from the 55th IACR Annual Conference. Cancers (Basel) 11, 1-11. doi:10.3390/cancers 11081125

Chavez, J. C., Bachmeier, C., and Kharfan-Dabaja, M. A. (2019). CAR T-Cell Therapy for B-Cell Lymphomas: Clinical Trial Results of Available Products. Ther. Adv. Hematol. 10, 2040620719841581. doi:10.1177/2040620719841581

Cheng, J., Zhao, L., Zhang, Y., Qin, Y., Guan, Y., Zhang, T., et al. (2019). Understanding the Mechanisms of Resistance to CAR T-Cell Therapy in Malignancies. Front. Oncol. 9, 1237-1239. doi:10.3389/fonc.2019.01237

Choe, J. H., Watchmaker, P. B., Simic, M. S., Gilbert, R. D., Li, A. W., Krasnow, N. A., et al. (2021). SynNotch-CAR T Cells Overcome Challenges of Specificity, Heterogeneity, and Persistence in Treating Glioblastoma. Sci. Transl Med. 13, eabe7378. doi:10.1126/scitranslmed.abe7378

Da Fonseca, L. G., and Carrilho, F. J. (2019). Updates in Immunotherapy for Hepatocellular Carcinoma. Hepatoma Res. 5, 37. doi:10.20517/23945079.2019.012

Dai, X., Mei, Y., Cai, D., and Han, W. (2019). Standardizing CAR-T Therapy: Getting it Scaled up. Biotechnol. Adv. 37, 239-245. doi:10.1016/ j.biotechadv.2018.12.002

Darvin, P., Toor, S. M., Sasidharan Nair, V., and Elkord, E. (2018). Immune Checkpoint Inhibitors: Recent Progress and Potential Biomarkers. Exp. Mol. Med. 50 (12), 1-11. doi:10.1038/s12276-018-0191-1

Dasgupta, A., Tinch, S., Szczur, K., Ernst, R., Shryock, N., Kaylor, C., et al. (2020). Phase I/II Manufacture of Lentiviral Vectors under GMP in an Academic Setting. Methods Mol. Biol. 2086, 27-60. doi:10.1007/978-1-0716-0146-4_3

Date, V., and Nair, S. (2021). Emerging Vistas in CAR T-Cell Therapy: Challenges and Opportunities in Solid Tumors. Expert Opin. Biol. Ther. 21 (2), 145-160. doi:10.1080/14712598.2020.1819978

Depil, S., Duchateau, P., Grupp, S. A., Mufti, G., and Poirot, L. (2020). 'Off-theshelf Allogeneic CAR T Cells: Development and Challenges. Nat. Rev. Drug Discov. 19, 185-199. doi:10.1038/s41573-019-0051-2

Dougan, M., and Dranoff, G. (2012). "Immunotherapy of Cancer," in The Innate Immune Regulation and Cancer Immunotherapy. Editors R.-F. Wang (New York: Springer-Verlag, 391-414. doi:10.1007/978-1-4419-9914-6_22

Dwivedi, A., Karulkar, A., Ghosh, S., Rafiq, A., and Purwar, R. (2019). Lymphocytes in Cellular Therapy: Functional Regulation of CAR T Cells. Front. Immunol. 9, 3180. doi:10.3389/fimmu.2018.03180

Edeline, J., Houot, R., Marabelle, A., and Alcantara, M. (2021). CAR-T Cells and BiTEs in Solid Tumors: Challenges and Perspectives. J. Hematol. Oncol. 14, 65-12. doi:10.1186/s13045-021-01067-5

Elahi, R., Khosh, E., Tahmasebi, S., and Esmaeilzadeh, A. (2018). Immune Cell Hacking: Challenges and Clinical Approaches to Create Smarter Generations of Chimeric Antigen Receptor T Cells. Front. Immunol. 9, 1717. doi:10.3389/ fimmu.2018.01717 
Eshhar, Z., Waks, T., Gross, G., and Schindler, D. G. (1993). Specific Activation and Targeting of Cytotoxic Lymphocytes through Chimeric Single Chains Consisting of Antibody-Binding Domains and the Gamma or Zeta Subunits of the Immunoglobulin and T-Cell Receptors. Proc. Natl. Acad. Sci. U S A. 90, 720-724. doi:10.1073/pnas.90.2.720

Euchner, J., Sprissler, J., Cathomen, T., Fürst, D., Schrezenmeier, H., Debatin, K.M., et al. (2021). Natural Killer Cells Generated from Human Induced Pluripotent Stem Cells Mature to CD56brightCD16+NKp80+/-In-Vitro and Express KIR2DL2/DL3 and KIR3DL1. Front. Immunol. 12, 1-11. doi:10.3389/ fimmu.2021.640672

Eyles, J. E., Vessillier, S., Jones, A., Stacey, G., Schneider, C. K., and Price, J. (2019). Cell Therapy Products: Focus on Issues with Manufacturing and Quality Control of Chimeric Antigen Receptor T-Cell Therapies. J. Chem. Technol. Biotechnol. 94, 1008-1016. doi:10.1002/jctb.5829

Fedorov, V. D., Themeli, M., and Sadelain, M. (2013). PD-1- and CTLA-4-Based Inhibitory Chimeric Antigen Receptors (iCARs) Divert Off-Target Immunotherapy Responses. Sci. Transl. Med. 5, 215ra172. doi:10.1126/ scitranslmed.3006597

Fernández, L., Fernández, A., Mirones, I., Escudero, A., Cardoso, L., Vela, M., et al. (2019). GMP-compliant Manufacturing of NKG2D CAR Memory T Cells Using CliniMACS Prodigy. Front. Immunol. 10, 2361-2372. doi:10.3389/ fimmu.2019.02361

Ferreira, M. V., Cabral, E. T., and Coroadinha, A. S. (2021). Progress and Perspectives in the Development of Lentiviral Vector Producer Cells. Biotechnol. J. 16, e2000017-12. doi:10.1002/biot.202000017

Fesnak, A., and O'Doherty, U. (2017). Clinical Development and Manufacture of Chimeric Antigen Receptor T Cells and the Role of Leukapheresis. Eur. Oncol. Haematol. 13, 28-34. doi:10.17925/eoh.2017.13.01.28

Fischer, J., Paret, C., El Malki, K., Alt, F., Wingerter, A., Neu, M. A., et al. (2017). CD19 Isoforms Enabling Resistance to CART-19 Immunotherapy Are Expressed in B-ALL Patients at Initial Diagnosis. J. Immunother. 40, 187-195. doi:10.1097/CJI.0000000000000169

Freitag, F., Maucher, M., Riester, Z., and Hudecek, M. (2020). New Targets and Technologies for CAR-T Cells. Curr. Opin. Oncol. 32 (5), 510-517. doi:10.1097/ CCO.0000000000000653

Fry, T. J., Shah, N. N., Orentas, R. J., Stetler-Stevenson, M., Yuan, C. M., Ramakrishna, S., et al. (2018). CD22-targeted CAR T Cells Induce Remission in B-ALL that Is Naive or Resistant to CD19-Targeted CAR Immunotherapy. Nat. Med. 24, 20-28. doi:10.1038/nm.4441

Fujiwara, K., Tsunei, A., Kusabuka, H., Ogaki, E., Tachibana, M., and Okada, N. (2020). Hinge and Transmembrane Domains of Chimeric Antigen Receptor Regulate Receptor Expression and Signaling Threshold. Cells 9 (5), 1182. doi:10.3390/cells9051182

Garber, K. (2019). Pursuit of Tumor-Infiltrating Lymphocyte Immunotherapy Speeds up. Nat. Biotechnol. 37, 969-971. doi:10.1038/d41587-019-00023-6

Gargett, T., and Brown, M. P. (2014). The Inducible Caspase-9 Suicide Gene System as a "safety Switch" to Limit On-Target, Off-Tumor Toxicities of Chimeric Antigen Receptor T Cells. Front. Pharmacol. 5, 235-237. doi:10.3389/fphar.2014.00235

Gee, A. P. (2018). GMP CAR-T Cell Production. Best Pract. Res. Clin. Haematol. 31, 126-134. doi:10.1016/j.beha.2018.01.002

Ghosh, A., Mailankody, S., Giralt, S. A., Landgren, C. O., Smith, E. L., and Brentjens, R. J. (2017). CAR T Cell Therapy for Multiple Myeloma: where Are We Now and where Are We Headed? Leuk. Lymphoma 59 (9), 2056-2067. doi:10.1080/10428194.2017.1393668

Golay, J., and Taylor, R. P. (2020). The Role of Complement in the Mechanism of Action of Therapeutic Anti-cancer mAbs. Antibodies (Basel) 9 (4), 58. doi:10.3390/antib9040058

Grosser, R., Cherkassky, L., Chintala, N., and Adusumilli, P. S. (2019). Combination Immunotherapy with CAR T Cells and Checkpoint Blockade for the Treatment of Solid Tumors. Cancer Cell 36, 471-482. doi:10.1016/ j.ccell.2019.09.006

Grupp, S. A., Kalos, M., Barrett, D., Aplenc, R., Porter, D. L., Rheingold, S. R., et al. (2013). Chimeric Antigen Receptor-Modified T Cells for Acute Lymphoid Leukemia. N. Engl. J. Med. 368, 1509-1518. doi:10.1056/NEJMoa1215134

Guedan, S., Ruella, M., and June, C. H. (2019). Emerging Cellular Therapies for Cancer. Annu. Rev. Immunol. 37, 145-171. doi:10.1146/annurev-immunol042718-041407
Gust, J., Taraseviciute, A., and Turtle, C. J. (2018). Neurotoxicity Associated with CD19-Targeted CAR-T Cell Therapies. CNS Drugs 32, 1091-1101. doi:10.1007/ s40263-018-0582-9

Haas, A. R., Tanyi, J. L., O’Hara, M. H., Gladney, W. L., Lacey, S. F., Torigian, D. A., et al. (2019). Phase I Study of Lentiviral-Transduced Chimeric Antigen Receptor-Modified T Cells Recognizing Mesothelin in Advanced Solid Cancers. Mol. Ther. 27, 1919-1929. doi:10.1016/j.ymthe.2019.07.015

Han, D., Xu, Z., Zhuang, Y., Ye, Z., and Qian, Q. (2021). Current Progress in CAR$\mathrm{T}$ Cell Therapy for Hematological Malignancies. J. Cancer 12, 326-334. doi:10.7150/JCA.48976

Han, X., Wang, Y., Wei, J., and Han, W. (2019). Multi-antigen-targeted Chimeric Antigen Receptor T Cells for Cancer Therapy. J. Hematol. Oncol. 12, 128-137. doi:10.1186/s13045-019-0813-7

Hansrivijit, P., Gale, R. P., Barrett, J., and Ciurea, S. O. (2019). Cellular Therapy for Acute Myeloid Leukemia - Current Status and Future Prospects. Blood Rev. 37, 100578. doi:10.1016/j.blre.2019.05.002

Hartmann, J., Schüßler-Lenz, M., Bondanza, A., and Buchholz, C. J. (2017). Clinical Development of CAR T Cells-Challenges and Opportunities in Translating Innovative Treatment Concepts. EMBO Mol. Med. 9, 1183-1197. doi:10.15252/emmm.201607485

Hassanpour, S. H., and Dehghani, M. (2017). Review of Cancer from Perspective of Molecular. J. Cancer Res. Pract. 4, 127-129. doi:10.1016/j.jcrpr.2017.07.001

Hay, A. E., and Cheung, M. C. (2019). CAR T-Cells: Costs, Comparisons, and Commentary. J. Med. Econ. 22, 613-615. doi:10.1080/13696998.2019.1582059

Hoffmann, J. M., Schubert, M. L., Wang, L., Hückelhoven, A., Sellner, L., Stock, S., et al. (2017). Differences in Expansion Potential of Naive Chimeric Antigen Receptor T Cells from Healthy Donors and Untreated Chronic Lymphocytic Leukemia Patients. Front. Immunol. 8, 1956. doi:10.3389/fimmu.2017.01956

Hollyman, D., Stefanski, J., Przybylowski, M., Bartido, S., Borquez-Ojeda, O., Taylor, C., et al. (2009). Manufacturing Validation of Biologically Functional T Cells Targeted to CD19 Antigen for Autologous Adoptive Cell Therapy. J. Immunother. 32, 169-180. doi:10.1097/CJI.0b013e318194a6e8

Hombach, A. A., and Abken, H. (2011). Costimulation by Chimeric Antigen Receptors Revisited The T Cell Antitumor Response Benefits From Combined CD28-OX40 Signalling. Int. J. Cancer 129 (12), 2935-2944. doi:10.1002/ijc.25960

Hong, R., Hu, Y., and Huang, H. (2021). Biomarkers for Chimeric Antigen Receptor T Cell Therapy in Acute Lymphoblastic Leukemia: Prospects for Personalized Management and Prognostic Prediction. Front. Immunol. 12, 627764. doi:10.3389/fimmu.2021.627764

Huang, R., Li, X., He, Y., Zhu, W., Gao, L., Liu, Y., et al. (2020). Recent Advances in CAR-T Cell Engineering. J. Hematol. Oncol. 13, 86-19. doi:10.1186/s13045020-00910-5

Iglesias-López, C., Agustí, A., Obach, M., and Vallano, A. (2019). Regulatory Framework for Advanced Therapy Medicinal Products in Europe and United States. Front. Pharmacol. 10, 1-14. doi:10.3389/fphar.2019.00921

Iragavarapu, C., and Hildebrandt, G. (2021). Lisocabtagene Maraleucel for the Treatment of B-Cell Lymphoma. Expert Opin. Biol. Ther. 28, 1-6. doi:10.1080/ 14712598.2021.1933939

Itzhaki, O., Jacoby, E., Nissani, A., Levi, M., Nagler, A., Kubi, A., et al. (2020). Headto-head Comparison of In-House Produced CD19 CAR-T Cell in ALL and NHL Patients. J. Immunother. Cancer 8, 1-10. doi:10.1136/jitc-2019-000148

Jan, M., Scarfò, I., Larson, R. C., Walker, A., Schmidts, A., Guirguis, A. A., et al. (2021). Reversible ON- and OFF-Switch Chimeric Antigen Receptors Controlled by Lenalidomide. Sci. Transl. Med. 13, eabb6295. doi:10.1126/ scitranslmed.abb6295

Kaiser, A. D., Assenmacher, M., Schröder, B., Meyer, M., Orentas, R., Bethke, U., et al. (2015). Towards a Commercial Process for the Manufacture of Genetically Modified T Cells for Therapy. Cancer Gene Ther. 22, 72-78. doi:10.1038/ cgt.2014.78

Kalos, M., Levine, B. L., Porter, D. L., Katz, S., Grupp, S. A., Bagg, A., et al. (2011). T Cells with Chimeric Antigen Receptors Have Potent Antitumor Effects. Sci. Transl Med. 3, 1-21. doi:10.1126/scitranslmed.3002842

Karlitepe, A., Ozalp, O., and Avci, C. B. (2015). New Approaches for Cancer Immunotherapy. Tumour Biol. 36 (6), 4075-4078. doi:10.1007/s13277-0153491-2

Kennedy, M., Awong, G., Sturgeon, C. M., Ditadi, A., LaMotte-Mohs, R., ZúñigaPflücker, J. C., et al. (2012). T Lymphocyte Potential Marks the Emergence of Definitive Hematopoietic Progenitors in Human Pluripotent Stem Cell 
Differentiation Cultures. Cel Rep 2, 1722-1735. doi:10.1016/ j.celrep.2012.11.003

Köhl, U., Arsenieva, S., Holzinger, A., and Abken, H. (2018). CAR T Cells in Trials: Recent Achievements and Challenges that Remain in the Production of Modified T Cells for Clinical Applications. Hum. Gene Ther. 29, 559-568. doi:10.1089/hum.2017.254

Kolonel, L. N., and Wilkens, L. R. "Migrant Studies," in Cancer Epidemiology and Prevention. Editors D. Schottenfeld and J. F. FraumeniJr. 3rd edn. (New York: Oxford University Press), 189-201.

Korell, F., Laier, S., Sauer, S., Veelken, K., Hennemann, H., Schubert, M. L., et al. (2020). Current Challenges In Providing Good Leukapheresis Products For Anufacturing of CAR-T Cells For Patients With Relapsed/Refractory NHL or ALL. Cells 9 (5), 1225. doi:10.3390/cells9051225

Krause, A., Guo, H. F., Latouche, J. B., Tan, C., Cheung, N. K. V., and Sadelain, M. (1998). Antigen-dependent CD28 Signaling Selectively Enhances Survival and Proliferation in Genetically Modified Activated Human Primary $\mathrm{T}$ Lymphocytes. J. Exp. Med. 188, 619-626. doi:10.1084/jem.188.4.619

Lança, T., and Silva-Santos, B. (2012). The Split Nature of Tumor-Infiltrating Leukocytes: Implications for Cancer Surveillance and Immunotherapy. Oncoimmunology 1, 717-725. doi:10.4161/onci.20068

Lee, D. W., Santomasso, B. D., Locke, F. L., Ghobadi, A., Turtle, C. J., Brudno, J. N., et al. (2019). ASTCT Consensus Grading for Cytokine Release Syndrome and Neurologic Toxicity Associated with Immune Effector Cells. Biol. Blood Marrow Transpl. 25, 625-638. doi:10.1016/j.bbmt.2018.12.758

Lester, J. F., Casbard, A. C., Al-Taei, S., Harrop, R., Katona, L., At-tanoos, R. L., et al. (2018). A Single centre Phase II Trial to Assess the Immunological Activity of TroVax ${ }^{\circledR}$ Plus Pemetrexed/cisplatin in Patients with Malignant Pleural Mesothelioma -the SKOPOS Trial. Oncoimmunology 7, e1457597. doi:10.1080/2162402x.2018.1457597

Levine, B. L., Miskin, J., Wonnacott, K., and Keir, C. (2017). Global Manufacturing of CAR T Cell Therapy. Mol. Ther. Methods Clin. Dev. 4, 92-101. doi:10.1016/ j.omtm.2016.12.006

Li, J., Li, W., Huang, K., Zhang, Y., Kupfer, G., and Zhao, Q. (2018). Chimeric Antigen Receptor T Cell (CAR-T) Immunotherapy for Solid Tumors: Lessons Learned and Strategies for Moving Forward. J. Hematol. Oncol. 11, 22. doi:10.1186/s13045-018-0568-6

Li, Y., Huo, Y., Yu, L., and Wang, J. (2019). Quality Control and Nonclinical Research on CAR-T Cell Products: General Principles and Key Issues. Engineering 5, 122-131. doi:10.1016/j.eng.2018.12.0010.1016/j.eng.2018.12.003

Ling, H. (2020). Chimeric-antigen Receptor T (CAR-T) Cell Therapy for Solid Tumor. IOP Conf. Ser. Mater. Sci. Eng. 768, 052051. doi:10.1088/1757-899X/ $768 / 5 / 052051$

Liu, B., Yan, L., and Zhou, M. (2019). Target Selection of CAR T Cell Therapy in Accordance with the TME for Solid Tumors. Am. J. Cancer Res. 9, 228-241. doi:10.1158/2159-8290.cd-rw2019-112

Lock, D., Mockel-Tenbrinck, N., Drechsel, K., Barth, C., Mauer, D., Schaser, T., et al. (2017). Automated Manufacturing of Potent CD20-Directed Chimeric Antigen Receptor T Cells for Clinical Use. Hum. Gene Ther. 28, 914-925. doi:10.1089/hum.2017.111

Lynn, R. C., Weber, E. W., Sotillo, E., Gennert, D., Xu, P., Good, Z., et al. (2019). c-Jun Overexpression in CAR T Cells Induces Exhaustion Resistance. Nature 576, 293-300. doi:10.1038/s41586-019-1805-z

Marks, P. (2019). The FDA's Regulatory Framework for Chimeric Antigen Receptor-T Cell Therapies. Clin. Transl. Sci. 12, 428-430. doi:10.1111/cts.12666

Martinez, M., and Moon, E. K. (2019). CAR T Cells for Solid Tumors: New Strategies for Finding, Infiltrating, and Surviving in the Tumor Microenvironment. Front. Immunol. 10, 1-21. doi:10.3389/fimmu.2019.00128

Maude, S. L., Frey, N., Shaw, P. A., Aplenc, R., Barrett, D. M., Bunin, N. J., et al. (2014). Chimeric Antigen Receptor T Cells for Sustained Remissions in Leukemia. N. Engl. J. Med. 371 (16), 1507-1517. doi:10.1056/NEJMoa1407222

Maude, S. L., Laetsch, T. W., Buechner, J., Rives, S., Boyer, M., Bittencourt, H., et al. (2018). Tisagenlecleucel in Children and Young Adults with B-Cell Lymphoblastic Leukemia. N. Engl. J. Med. 378, 439-448. doi:10.1056/ nejmoa1709866

Maude, S. L., Laetsch, T. W., Buechner, J., Rives, S., Boyer, M., Bittencourt, H., et al. (2018). Tisagenlecleucel in Children and Young Adults with B-Cell Lymphoblastic Leukemia. N. Engl. J. Med. 378 (5), 439-448. doi:10.1056/ NEJMoa1709866
Miao, L., Zhang, Z., Ren, Z., and Li, Y. (2021). Reactions Related to CAR-T Cell Therapy. Front. Immunol. 12, 1501. doi:10.3389/fimmu.2021.663201

Miller, J. (1961). Immunological Function of the Thymus. The Lancet 278, 748-749. doi:10.1016/s0140-6736(61)90693-6

Milone, M. C., Fish, J. D., Carpenito, C., Carroll, R. G., Binder, G. K., June, C. H., et al. (2009). Chimeric Receptors Containing CD137 Signal Transduction Domains Mediate Enhanced Survival of T Cells and Increased Antileukemic Efficacy In Vivo. Mol. Ther. 17 (8), 1453-1464. doi:10.1038/mt.2009.83

Mirzaei, H. R., Mirzaei, H., Namdar, A., Rahmati, M., Till, B. G., and Hadjati, J. (2018). Predictive and Therapeutic Biomarkers in Chimeric Antigen Receptor T-Cell Therapy: A Clinical Perspective. J. Cel. Physiol. 234, 5827-5841. doi:10.1002/jcp.27519

Mirzaei, H. R., Rodriguez, A., Shepphird, J., Brown, C. E., and Badie, B. (2017). Chimeric Antigen Receptors T Cell Therapy in Solid Tumor: Challenges and Clinical Applications. Front. Immunol. 8, 1850. doi:10.3389/ fimmu.2017.01850

Monajati, M., Abolmaali, S. S., and Tamaddon, A. (2021). 2020 FDA/EMA Approvals for New Immunotherapy Drug Technologies and Applications. J. Glob. Trends. Pharm. Sci. 7 (2), 81-92. doi:10.30476/tips.2021.91207.1097

Mondal, M., Guo, J., He, P., and Zhou, D. (2020). Recent Advances of Oncolytic Virus in Cancer Therapy. Hum. Vaccin. Immunother. 16 (10), 2389-2402. doi:10.1080/21645515.2020.1723363

Mullard, A. (2017). FDA Approves First CAR T Therapy. Nat. Rev. Drug Discov. 16, 669. doi:10.1038/nrd.2017.196

Munshi, C. N., Anderson, L. D., Shah, N., Madduri, D., Berdeja, J., Lonial, S., et al. (2021). Idecabtagene Vicleucel in Relapsed and Refractory Multiple Myeloma. N. Engl. J. Med. 384, 705-716. doi:10.1056/NEJMoa2024850

Nair, S., Wang, J. B., Tsao, S. T., Liu, Y., Zhu, W., Slayton, W. B., et al. (2019). Functional Improvement of Chimeric Antigen Receptor through Intrinsic interleukin-15Ra Signaling. Curr. Gene Ther. 19 (1), 40-53. doi:10.2174/ 1566523218666181116093857

Neelapu, S. S., Locke, F. L., Bartlett, N. L., Lekakis, L. J., Miklos, D. B., Jacobson, C. A., et al. (2017). Axicabtagene Ciloleucel CAR T-Cell Therapy in Refractory Large B-Cell Lymphoma. N. Engl. J. Med. 377, 2531-2544. doi:10.1056/ NEJMoa1707447

Neelapu, S. S., Tummala, S., Kebriaei, P., Wierda, W., Gutierrez, C., Locke, F. L., et al. (2018). Chimeric Antigen Receptor T-Cell Therapy - Assessment and Management of Toxicities. Nat. Rev. Clin. Oncol. 15, 47-62. doi:10.1038/ nrclinonc. 2017.148

Neill, L., Rees, J., and Roddie, C. (2020). Neurotoxicity -CAR T-Cell Therapy: What the Neurologist Needs to Know. Pract. Neurol. 20, 287-295. doi:10.1136/ practneurol-2020-002550

Nejad, A. S., Noor, T., Munim, Z. H., and Alikhani My Ghaemi, A. (2021). A Bibliometric Review of Oncolytic Virus Research as a Novel Approach for Cancer Therapy. Virol. J. 18, 98. doi:10.1186/s12985-021-01571-7

Nianias, A., and Themeli, M. (2019). Induced Pluripotent Stem Cell (iPSC)-Derived Lymphocytes for Adoptive Cell Immunotherapy: Recent Advances and Challenges. Curr. Hematol. Malig. Rep. 14, 261-268. doi:10.1007/s11899-019-00528-6

Nie, Y., Lu, W., Chen, D., Tu, H., Guo, Z., Zhou, X., et al. (2020). Mechanisms Underlying CD19-Positive ALL Relapse after Anti-CD19 CAR T Cell Therapy and Associated Strategies. Biomark. Res. 8, 1-17. doi:10.1186/s40364-02000197-1

Nobles, C. L., Sherrill-Mix, S., Everett, J. K., Reddy, S., Fraietta, J. A., Porter, D. L., et al. (2020). CD19-targeting CAR T Cell Immunotherapy Outcomes Correlate with Genomic Modification by Vector Integration. J. Clin. Invest. 130, 673-685. doi:10.1172/JCI130144

Orlando, E. J., Han, X., Tribouley, C., Wood, P. A., Leary, R. J., Riester, M., et al. (2018). Genetic Mechanisms of Target Antigen Loss in CAR19 Therapy of Acute Lymphoblastic Leukemia. Nat. Med. 24, 1504-1506. doi:10.1038/s41591018-0146-z

Papaioannou, N. E., Beniata, O. V., Vitsos, P., Tsitsilonis, O., and Samara, P. (2016). Harnessing the Immune System to Improve Cancer Therapy. Ann. Transl. Med. 4, 261. doi:10.21037/atm.2016.04.01

Papathanasiou, M. M., Stamatis, C., Lakelin, M., Farid, S., Titchener-Hooker, N., and Shah, N. (2020). Autologous CAR T-Cell Therapies Supply Chain: Challenges and Opportunities? Cancer Gene Ther. 27, 799-809. doi:10.1038/ s41417-019-0157-z 
Park, J. H., Rivière, I., Gonen, M., Wang, X., Sénéchal, B., Curran, K. J., et al. (2018). Long-Term Follow-Up of CD19 CAR Therapy in Acute Lymphoblastic Leukemia. N. Engl. J. Med. 378, 449-459. doi:10.1056/nejmoa1709919

Parmiani, G., Rivoltini, L., Andreola, G., and Carrabba, M. (2000). Cytokines in Cancer Therapy. Immunol. Lett. 74 (1), 41-44. doi:10.1016/S0165-2478(00) 00247-9

Petersen, C. T., and Krenciute, G. (2019). Next Generation CAR T Cells for the Immunotherapy of High-Grade Glioma. Front. Oncol. 9, 1-9. doi:10.3389/ fonc.2019.00069

Pont, M. J., Hill, T., Cole, G. O., Abbott, J. J., Kelliher, J., Salter, A. I., et al. (2019). $\gamma$-Secretase Inhibition Increases Efficacy of BCMA-specific Chimeric Antigen Receptor T Cells in Multiple Myeloma. Blood 134 (19), 1585-1597. doi:10.1182/ blood.2019000050

Ponterio, E., De Maria, R., and Haas, T. L. (2020). Identification of Targets to Redirect CAR T Cells in Glioblastoma and Colorectal Cancer: An Arduous Venture. Front. Immunol. 11, 1-12. doi:10.3389/fimmu.2020.565631

Poorebrahim, M., Melief, J., Pico de Coaña Y, L., Wickström, S., Cid-Arregui, A., and Kiessling, R. (2020). Counteracting CAR T Cell Dysfunction. Oncogene 40, 421-435. doi:10.1038/s41388-020-01501-x

Porter, D. L., Hwang, W. T., Frey, N. V., Lacey, S. F., Shaw, P. A., Loren, A. W., et al. (2015). Chimeric Antigen Receptor T Cells Persist and Induce Sustained Remissions in Relapsed Refractory Chronic Lymphocytic Leukemia. Sci. Transl. Med. 7, 303ra139. doi:10.1126/scitranslmed.aac5415

Qin, V. M., D'Souza, C., Neeson, P. J., and Zhu, J. J. (2021). Chimeric Antigen Receptor beyond CAR-T Cells. Cancers (Basel) 13, 404. doi:10.3390/ cancers 13030404

Qiu, Y., Su, M., Liu, L., Tang, Y., Pan, Y., and Sun, J. (2021). Clinical Application of Cytokines in Cancer Immunotherapy. Drug Des. Devel Ther. 27 (15), 2269-2287. doi:10.2147/DDDT.S308578

Rafiq, S., Hackett, C. S., and Brentjens, R. J. (2020). Engineering Strategies to Overcome the Current Roadblocks in CAR T Cell Therapy. Nat. Rev. Clin. Oncol. 17, 147-167. doi:10.1038/s41571-019-0297-y

Ramello, M. C., Benzaïd, I., Kuenzi, B. M., Lienlaf-Moreno, M., Kandell, W. M., Santiago, D. N., et al. (2019). An Immunoproteomic Approach to Characterize the CAR Interactome and Signalosome. Sci. Signal. 12 (568), eaap9777. doi:10.1126/scisignal.aap9777

Riegler, L. L., Jones, G. P., and Lee, D. W. (2019). Current Approaches in the Grading and Management of Cytokine Release Syndrome after Chimeric Antigen Receptor T-Cell Therapy. Ther. Clin. Risk Manag. 15, 323-335. doi:10.2147/TCRM.S150524

Roddie, C., O'Reilly, M., Dias Alves Pinto, J., Vispute, K., and Lowdell, M. (2019). Manufacturing Chimeric Antigen Receptor T Cells: Issues and Challenges. Cytotherapy 21, 327-340. doi:10.1016/j.jcyt.2018.11.009

Rodriguez-Garcia, A., Palazon, A., Noguera-Ortega, E., Powell, D. J., and Guedan, S. (2020). CAR-T Cells Hit the Tumor Microenvironment: Strategies to Overcome Tumor Escape. Front. Immunol. 11, 1-17. doi:10.3389/ fimmu.2020.01109

Rodríguez-Otero, P., Prósper, F., Alfonso, A., Paiva, B., and San Miguel, J. F. (2020). CAR T-Cells in Multiple Myeloma Are Ready for Prime Time. J. Clin. Med. 9 (11), 3577. doi:10.3390/jcm9113577

Rohaan, M. W., Wilgenhof, S., and Haanen, J. B. A. G. (2019). Adoptive Cellular Therapies: the Current Landscape. Virchows Arch. 474 (4), 449-461. doi:10.1007/s00428-018-2484-0

Roselli, E., Frieling, J. S., Thorner, K., Ramello, M. C., Lynch, C. C., and AbateDaga, D. (2019). CAR-T Engineering: Optimizing Signal Transduction and Effector Mechanisms. BioDrugs 33 (6), 647-659. doi:10.1007/s40259-019-00384-z

Rosenberg, S. A., Spiess, P., and Lafreniere, R. (1986). A New Approach to the Adoptive Immunotherapy of Cancer with Tumor-Infiltrating Lymphocytes. Science 233, 1318-1321. doi:10.1126/science.3489291

Sadelain, M., Brentjens, R., and Rivière, I. (2009). The Promise and Potential Pitfalls of Chimeric Antigen Receptors. Curr. Opin. Immunol. 21, 215-223. doi:10.1016/j.coi.2009.02.009

Sadelain, M. (1997). Methods for Retrovirus-Mediated Gene Transfer into Primary T-Lymphocytes. Methods Mol. Med. 17, 241-248. doi:10.1385/0-89603-484-4:241

Sadelain, M., and Mulligan, R. C. (1992). Efficient Transduction of Murine Primary T Lymphocytes in 8th International Congress of Immunology Ed International Congress of Immunology. Springer-Verlag.
Sang, W., Zhang, Z., Dai, Y., and Chen, X. (2019). Recent Advances in Nanomaterial-Based Synergistic Combination Cancer Immunotherapy. Chem. Soc. Rev. 48, 3771-3810. doi:10.1039/c8cs00896e

Scarfò, I., Ormhøj, M., Frigault, M. J., Castano, A. P., Lorrey, S., Bouffard, A. A., et al. (2018). Anti-CD37 Chimeric Antigen Receptor T Cells Are Active against B- and T-Cell Lymphomas. Blood 132 (14), 1495-1506. doi:10.1182/blood2018-04-842708

Scheuermann, R. H., and Racila, E. (1995). CD19 Antigen in Leukemia and Lymphoma Diagnosis and Immunotherapy. Leuk. Lymphoma 18, 385-397. doi:10.3109/10428199509059636

Schumacher, T. N., Kesmir, C., and van Buuren, M. M. (2015). Biomarkers in Cancer Immunotherapy. Cancer Cel.l 27, 12-14. doi:10.1016/j.ccell.2014.12.004

Schuster, S. J., Bishop, M. R., Tam, C. S., Waller, E. K., Borchmann, P., McGuirk, J. P., et al. (2019). Tisagenlecleucel in Adult Relapsed or Refractory Diffuse Large B-Cell Lymphoma. N. Engl. J. Med. 380 (1), 45-56. doi:10.1056/ NEJMoa 1804980

Seo, H., Chen, J., Samaniego-castruita, D., Wang, Y. H., López-moyado, I. F., Georges, O., et al. (2019). Correction: TOX and TOX2 Transcription Factors Cooperate with NR4A Transcription Factors to Impose CD8+ Tcell Exhaustion. Proc. Natl. Acad. Sci. U. S. A. 116, 19761. doi:10.1073/ pnas. 1914896116

Shah, N. N., Highfill, S. L., Shalabi, H., Yates, B., Jin, J., Wolters, P. L., et al. (2020b). CD4/CD8 T-Cell Selection Affects Chimeric Antigen Receptor (CAR) T-Cell Potency and Toxicity: Updated Results from a Phase I Anti-CD22 CAR T-Cell Trial. J. Clin. Oncol. 38, 1938-1950. doi:10.1200/JCO.19.03279

Shah, N. N., Johnson, B. D., Schneider, D., Zhu, F., Szabo, A., Keever-Taylor, C. A., et al. (2020a). Bispecific Anti-CD20, Anti-CD19 CAR T Cells for Relapsed B Cell Malignancies: a Phase 1 Dose Escalation and Expansion Trial. Nat. Med. 26 (10), 1569-1575. doi:10.1038/s41591-020-1081-3

Shen, C., Zhang, Z., and Zhang, Y. (2020). Chimeric Antigen Receptor T Cell Exhaustion during Treatment for Hematological Malignancies. Biomed. Res. Int. 2020, 1-9. doi:10.1155/2020/8765028

Shirasu, N., and Kuroki, M. (2012). Functional Design of Chimeric T-Cell Antigen Receptors for Adoptive Immunotherapy of Cancer: Architecture and Outcomes. Anticancer Res. 32 (6), 2377-2383.

Siegel, R. L., Miller, K. D., and Jemal, A. (2019). Cancer Statistics. CA Cancer J. Clin. 69, 7-34. doi:10.3322/caac. 21551

Siegler, E. L., and Kenderian, S. S. (2020). Neurotoxicity and Cytokine Release Syndrome after Chimeric Antigen Receptor T Cell Therapy: Insights into Mechanisms and Novel Therapies. Front. Immunol. 11, 1-11. doi:10.3389/ fimmu.2020.01973

Singh, A. K., and McGuirk, J. P. (2020). CAR T Cells: Continuation in a Revolution of Immunotherapy. Lancet Oncol. 21, e168-e178. doi:10.1016/S1470-2045(19) 30823-X

Sotillo, E., Barrett, D. M., Black, K. L., Bagashev, A., Oldridge, D., Wu, G., et al. (2015). Convergence of Acquired Mutations and Alternative Splicing of CD19 Enables Resistance to CART-19 Immunotherapy. Cancer Discov. 5, 1282-1295. doi:10.1158/2159-8290.CD-15-1020

Springuel, L., Lonez, C., Alexandre, B., Van Cutsem, E., Machiels, J. P. H., Van Den Eynde, et al. (2019). Chimeric Antigen Receptor-T Cells for Targeting Solid Tumors: Current Challenges and Existing Strategies. BioDrugs 33 (5), 515-537. doi:10.1007/s40259-019-00368-z

Stock, S., Schmitt, M., and Sellner, L. (2019). Optimizing Manufacturing Protocols of Chimeric Antigen Receptor $\mathrm{T}$ Cells for Improved Anticancer Immunotherapy. Int. J. Mol. Sci. 20 (24), 6223. doi:10.3390/ijms20246223

Stroncek, D. F., Lee, D. W., Ren, J., Sabatino, M., Highfill, S., Khuu, H., et al. (2017). Elutriated Lymphocytes for Manufacturing Chimeric Antigen Receptor T Cells. J. Transl. Med. 15, 4-11. doi:10.1186/s12967-017-1160-5

Swiech, K., Malmegrim, K. C. R., and Picanço-Castro, V. (2020). Chimeric Antigen Receptor T Cells: Development and Production. Springer Protocols. doi:10.1007/ 978-1-0716-0146-4

Tahmasebi, S., Elahi, R., and Esmaeilzadeh, A. (2019). Solid Tumors Challenges and New Insights of CAR T Cell Engineering. Stem Cel Rev. Rep. 15, 619-636. doi:10.1007/s12015-019-09901-7

Tang, L., Zhang, Y., Hu, Y., and Mei, H. (2021). T Cell Exhaustion and CAR-T Immunotherapy in Hematological Malignancies. Biomed. Res. Int. 2021, 1-8. doi:10.1155/2021/6616391 
Tedder, T. F. (2009). CD19: a Promising B Cell Target for Rheumatoid Arthritis. Nat. Rev. Rheumatol. 5, 572-577. doi:10.1038/nrrheum.2009.184

Thomas, E. D., Lochte, H. L., Lu, W. C., and Ferrebee, J. W. (1957). Intravenous Infusion of Bone Marrow in Patients Receiving Radiation and Chemotherapy. N. Engl. J. Med. 257, 491-496. doi:10.1056/ NEJM195709122571102

Townsend, M. H., Shrestha, G., Robison, R. A., and O’Neill, K. L. (2018). The Expansion of Targetable Biomarkers for CAR T Cell Therapy. J. Exp. Clin. Cancer Res. 37, 1-23. doi:10.1186/s13046-018-0817-0

Twomey, J. D., and Zhang, B. (2021). Cancer Immunotherapy Update: FDAApproved Checkpoint Inhibitors and Companion Diagnostics. AAPS J. 23 (2), 39. doi:10.1208/s12248-021-00574-0

U.S. Food and Drug Administrations (2021a). KYMRIAH (Tisagenlecleucel). Available at: https://www.fda.gov/vaccines-blood-biologics/cellulargenetherapy-products/kymriah-tisagenlecleucel.

U.S. Food and Drug Administrations (2021b). Abecma (Idecabtagene Vicleucel). Available at: https://www.fda.gov/news-events/pressannouncements/ fdaapproves-first-cell-based-gene-therapy-adult-patients-multiple-myeloma.

U.S. Food and Drug Administrations (2021c). YESCARTA (Axicabtagene Ciloleucel). Available at: https:/www.fda.gov/vaccines-blood-biologics/ cellular-gene-therapy-products/yescarta-axicabtagene-ciloleucel.

Van der Stegen, S. J., Hamieh, M., and Sadelain, M. (2015). The Pharmacology of Second-Generation Chimeric Antigen Receptors. Nat. Rev. Drug Discov. 14 (7), 499-509. doi:10.1038/nrd4597

Varadé, J., Magadán, S., and González-Fernández, Á. (2021). Human Immunology and Immunotherapy: Main Achievements and Challenges. Cell. Mol. Immunol. 18, 805-828. doi:10.1038/s41423-020-00530-6

Ventola, C. L. (2017). Cancer Immunotherapy, Part 3: Challenges and Future Trends. P T. 42 (8), 514-521. doi:10.1007/978-3-319-17900-1_176

Waldmann, T. A. (2003). Immunotherapy: Past, Present and Future. Nat. Med. 9, 269-277. doi:10.1038/nm0303-269

Wang, K., Wei, G., and Liu, D. (2012). CD19: a Biomarker for B Cell Development, Lymphoma Diagnosis and Therapy. Exp. Hematol. Onco. 1, 1-7. doi:10.1186/ 2162-3619-1-36

Wang, M., Pruteanu, 1., Cohen, A. D., Garfall, A. L., Milone, M. C., Tian, L., et al. (2019). Identification and Validation of Predictive Biomarkers to CD19- and BCMA-specific CAR T-Cell Responses in CAR T-Cell Precursors. Blood 134, 622. doi:10.1182/blood-2019-122513

Wang, X., and Rivière, I. (2016). Clinical Manufacturing of CAR T Cells: Foundation of a Promising Therapy. Mol. Ther. Oncolytics. 3, 16015. doi:10.1038/mto.2016.15

Wang, Z., Wu, Z., Liu, Y., and Han, W. (2017). New Development in CAR-T Cell Therapy. J. Hematol. Oncol. 10, 1-11. doi:10.1186/s13045-017-0423-1

Wei, J., Han, X., Bo, J., and Han, W. (2019). Target Selection for CAR-T Therapy. J. Hematol. Oncol. 12, 1-9. doi:10.1186/s13045-019-0758-x

Wherry, E. J. (2011). T Cell Exhaustion. Nat. Immunol. 12, 492-499. doi:10.1038/ni.2035

Xie, G., Dong, H., Liang, Y., Ham, J. D., Rizwan, R., and Chen, J. (2020). CAR-NK Cells: A Promising Cellular Immunotherapy for Cancer. EBioMedicine 59, 102975. doi:10.1016/j.ebiom.2020.102975

Xu, X., Sun, Q., Liang, X., Chen, Z., Zhang, X., Zhou, X., et al. (2019). Mechanisms of Relapse after CD19 CAR T-Cell Therapy for Acute Lymphoblastic Leukemia and its Prevention and Treatment Strategies. Front. Immunol. 10, 1-15. doi:10.3389/fimmu.2019.02664

Yadav, R. K., Ali, A., Kumar, S., Sharma, A., Baghchi, B., Singh, P., et al. (2020). CAR T Cell Therapy: Newer Approaches to Counter Resistance and Cost. Heliyon 6, e03779. doi:10.1016/j.heliyon.2020.e03779

Yakoub-Agha, I., Chabannon, C., Bader, P., Basak, G. W., Bonig, H., Ciceri, F., et al. (2020). Management of Adults and Children Undergoing Chimeric Antigen Receptor T-Cell Therapy: Best Practice Recommendations of the European Society for Blood and Marrow Transplantation (EBMT) and the Joint Accreditation Committee of ISCT and EBMT (JACIE). Haematologica 105, 297-316. doi:10.3324/haematol.2019.229781

Yazdanifar, M., Barbarito, G., Bertaina, A., and Airoldi, I. (2020). Г $\delta$ T Cells: The Ideal Tool for Cancer Immunotherapy. Cells 9, 1-26. doi:10.3390/cells9051305

Yu, S., Yi, M., Qin, S., and Wu, K. (2019). Next Generation Chimeric Antigen Receptor T Cells: Safety Strategies to Overcome Toxicity. Mol. Cancer 18, 125-137. doi:10.1186/s12943-019-1057-4

Zah, E., Lin, M. Y., Anne, S. B., Jensen, M. C., and Chen, Y. Y. (2016). T Cells Expressing CD19/CD20 Bispecific Chimeric Antigen Receptors Prevent Antigen Escape by Malignant B Cells. Cancer Immunol. Res. 4, 498-508. doi:10.1158/2326-6066.CIR-15-0231

Zahavi, D., and Weiner, L. (2020). Monoclonal Antibodies in Cancer Therapy. Antibodies 9, 34. doi:10.3390/antib9030034

Zeng, J., Tang, S. Y., Toh, L. L., and Wang, S. (2017). Generation of "Off-The-Shelf" Natural Killer Cells from Peripheral Blood Cell-Derived Induced Pluripotent Stem Cells. Stem Cel Rep. 9, 1796-1812. doi:10.1016/j.stemcr.2017.10.020

Zhang, Y., Zhang, W., Dai, H., Wang, Y., Shi, F., Wang, C., et al. (2016). An Analytical Biomarker for Treatment of Patients with Recurrent B-ALL after Remission Induced by Infusion of Anti-CD19 Chimeric Antigen Receptor T (CAR-T) Cells. Sci. China Life Sci. 59, 379-385. doi:10.1007/s11427-016-5035-4

Zhao, Z., Xiao, X., Saw, P. E., Wu, W., Huang, H., Chen, J., et al. (2020). Chimeric Antigen Receptor $\mathrm{T}$ Cells in Solid Tumors: a War against the Tumor Microenvironment. Sci. China Life Sci. 63, 180-205. doi:10.1007/s11427019-9665-8

Conflict of Interest: The authors declare that the research was conducted in the absence of any commercial or financial relationships that could be construed as a potential conflict of interest.

Publisher's Note: All claims expressed in this article are solely those of the authors and do not necessarily represent those of their affiliated organizations, or those of the publisher, the editors and the reviewers. Any product that may be evaluated in this article, or claim that may be made by its manufacturer, is not guaranteed or endorsed by the publisher.

Copyright (C) 2021 Hernández-López, Téllez-González, Mondragón-Terán and Meneses-Acosta. This is an open-access article distributed under the terms of the Creative Commons Attribution License (CC BY). The use, distribution or reproduction in other forums is permitted, provided the original author(s) and the copyright owner(s) are credited and that the original publication in this journal is cited, in accordance with accepted academic practice. No use, distribution or reproduction is permitted which does not comply with these terms. 